\title{
OF HUMAN SACRIFICE AND BARBARITY: A CASE STUDY OF THE LATE ARCHAIC TUMULUS XVII AT ISTROS*
}

\author{
Sobre o sacrificio humano e a barbárie: Um estudo de \\ caso do Tumulus XVII da Era Arcaica Tardia em Istros
}

\section{Michael Anthony Fowler ${ }^{l}$}

\begin{abstract}
This article consists of a detailed examination of one of four Late Archaic-era funerary monuments that were excavated in the mid-1950s in the Northern Necropolis of the Pontic Greek settlement of Istros. The exploration of this monument, Tumulus XVII (circa 550-525 BC), revealed several features that were immediately compared to the heroic cremation burials, as described in epic poetry (particularly the funeral of Patroklos in Homer's Iliad). What most attracted attention were the remains of three human victims of sacrifice. Despite the early connection drawn with Homeric epic, for the next three decades Tumulus XVII was classified as a non-Greek (Thracian) monument, principally due to the presence of human sacrifices. In other words, human sacrifice was regarded as primitive and thus foreign to the more 'advanced' Greek culture. For this reason, the evidence from Istros did not have a prominent place in studies related to Greek human sacrifice. However, the growing body of research on Greek and indigenous settlements and cemeteries on the western coast of the Black Sea, along with the more recent discovery of the remains of a bound and decapitated man next to
\end{abstract}

\footnotetext{
" I wish to thank Erica Angliker and Lorena Lopes for their invitation to contribute to this volume, as well as the anonymous reviewers for their critical comments. This article expands upon a section of my Ph.D. dissertation "Human Sacrifice in Greek Antiquity: Between Myth, Image, and Reality" (Columbia University, 2019); accordingly, I would also like to thank the members of my doctoral committee, especially Ioannis Mylonopoulos, for their guidance and feedback on my overall project. The initial stages of research and writing on the Late Archaic tumuli at Istros were completed in summer 2014 at the Institute for Classical Archaeology, University of Tübingen, where I held a Teach@Tübingen Fellowship. I am grateful to my colleagues and seminar students at the Institute for their hospitality, support, and interest in my research. Additional critical support of this research came in 2015-2016 in the form of an Alexander S. Onassis Foreigners' Fellowship and a C.V. Starr Dissertation Finishing Grant (Columbia). Any errors or shortcomings that remain are, of course, my own.

1 Assistant Professor of Art History. East Tennessee State University. Email: fowlerma@etsu.edu.
} 
Pyre A at Orthi Petra (circa 700 BC; Eleutherna, Crete), has occasioned the reconsideration of the original barbarian characterization of Tumulus XVII. The funerary rituals and resulting tumular monument seem to have been developed by a subset of the elite of the Greek colonial community as a means to distinguish and elevate themselves among the ever-growing population of the city. While epic may have lent general inspiration and significance to the particular rituals performed, a more immediate model for the tumular form may have been taken from the 'heroon' (late $7^{\text {th }}$ cent. BC) in the necropolis of the nearby Greek settlement of Orgame. Although the precise circumstances surrounding the funerary human sacrifices escape us, this short-lived ritual phenomenon seems rather to have been introduced to the region by Greek settlers.

Keywords: Human sacrifice, archaeology of ritual, Archaic Greece, Thrace, Black Sea, cultural interaction.

\section{RESUMO}

Este artigo consiste em um exame detalhado de um dos quatro monumentos tumulares da Era Arcaica Tardia que foram escavados em meados da década de 1950 na necrópole do norte do assentamento grego de Istros. A investigação desse monumento, Tumulus XVII (circa 550-525 a.C.), revelou várias características que foram imediatamente comparadas às sepulturas de cremação heróicas, conforme descrito na poesia épica (particularmente no funeral de Pátroclo na Ilíada de Homero). O que mais chamou atenção foram os restos mortais de três vítimas humanas de sacrifício. Apesar da conexão inicial com a epopéia homérica, nas três décadas seguintes, o Tumulus XVII foi classificado como um monumento não grego (trácio), principalmente devido à presença de sacrifícios humanos. Ou seja, o sacrifício humano era considerado muito primitivo e, portanto, estranho à cultura grega mais "avançada". Por essa razão, a evidência de Istros não teve um lugar proeminente nos estudos relacionados ao sacrifício humano grego. No entanto, o crescente corpus de pesquisas sobre assentamentos e cemitérios gregos e indígenas no oeste do Mar Negro, junto com a descoberta mais recente de um homem amarrado e decapitado, ritualmente, ao lado da Pira A em Orthi Petra (cerca de 700 a.C., em Eleutherna, Creta), ocasionou a reconsideração da caracterização bárbara original de Tumulus XVII. Os rituais funerários e o monumento tumular resultante parecem ter sido desenvolvidos por um subconjunto da elite da comunidade colonial grega como um meio de se distinguir e se elevar em relação à população cada vez maior da cidade. Enquanto a epopéia pode ter emprestado inspiração e significado aos rituais específicos realizados, um modelo mais imediato para a forma tumular pode ter sido retirado do "herôon" (ao final do século 7 a.C.) na necrópole do assentamento grego próximo de Orgame. Embora as circunstâncias precisas em torno dos sacrifícios humanos funerários nos escapem, esse fenômeno ritual de curta duração parece ter sido introduzido na região pelos colonos gregos.

Palavras-chave: Sacrifício humano; Arqueologia do ritual; Grécia Arcaica; Trácia; Mar Negro; Interação cultural. 


\section{Introduction}

By the Archaic period, traditional epic tales were collectively elaborated in poetic forms and diffused across time and space through vocal performance. Despite the social and political transformations that occurred in communities across the Archaic Greek world, elites continued to compete for power and pre-eminence within their localities and regions. While epic tales began to take shape in the Early Iron Age and thus probably reflect, to a great degree, the contemporary culture and the ethos of the aristocracy, in the Archaic era, epic acquired even more significance as a potential source of inspiration for elites seeking to elevate their status by adapting and adopting behaviors of the generation of heroes and/or by directly appropriating aspects of their storied pasts.

Funerary human sacrifice is one of the most intense and extraordinary ritual behaviors that are attested in extant Greek myth and epic (cf. the 12 Trojan youths slaughtered at the pyre of Patroklos in Homer's Iliad; or the Trojan princess Polyxena sacrificed at the tomb of Achilles in the Iliou Persis of the Epic Cycle, according to the prose plot synopsis relayed in Proklos' Chrestomathy). ${ }^{2}$ That said, historical instances of such sacrifices have been proposed, based on archaeological remains, at Geometric- and Archaicera sites in Greece. ${ }^{3}$ In this contribution, I focus on an archaeologically documented case from the periphery of the Greek world: Tumulus XVII in the Northern Necropolis of the Milesian Pontic colony of Istros, where the evident practice human sacrifice is just one of several material features that

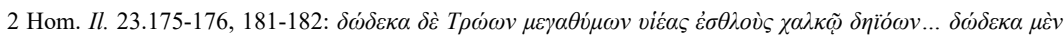

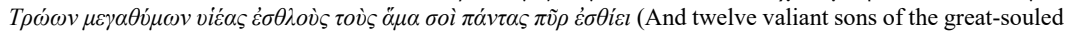
Trojans slew he with the bronze...Twelve valiant sons of the great-souled Trojans, lo all these together with the flame devoureth; trans. MURRAY, 1925 [1976], pp. 507-509). Proklos Chrest. 2 (wherein the lost poem

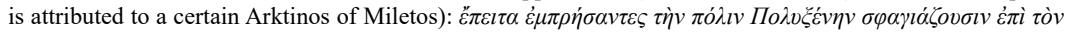

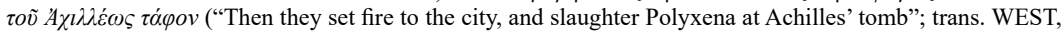
2003, p. 147). Dissimilar to the slaughtering of the Trojan youths, the sacrifice of Polyxena is represented on multiple Archaic-era works of art, principally vases, dating as far back as the $7^{\text {th }}$ century, providing precious, early visual testimony of this mythic episode in default of an intact textual record of the abovementioned poetic version. For a succinct presentation of the iconographic evidence see MYLONOPOULOS, 2013.

3 Most notably and unambiguously, the beheaded and dismembered adult man found at the corner of Pyre A in the Orthi Petra cemetery at Eleutherna (Crete; circa 700 BC). For the principal publication of this find see STAMPOLIDIS, 1996. The earliest (Middle Protogeometric), though far less certain, instance of funerary human sacrifice in post-Mycenaean Greece has been argued in the case of the young woman inhumed within the Toumba building at Lefkandi, for which see POPHAM; CALLIGAS; SACKETT, 1993.
} 
scholars have compared to epic funerals. ${ }^{4}$ Pointing to opinions preserved in literary sources from the Classical period and beyond, however, several scholars have held the view that human sacrifice was repugnant to the Greeks, who saw it as a perversion or inversion of sacrificial norms and, by extension, a barbaric act. ${ }^{5}$ The present case study of Tumulus XVII in Istros and the history of the scholarship relevant to it will show why maintaining too firmly a literary understanding of ancient Greek culture can cause scholars to miss or misunderstand unusual or supposedly 'foreign' phenomena in the archaeological record. Indeed, at Istros, this is exactly what happened when it was discovered that multiple tumuli contained skeletal remains interpreted as those of sacrificial victims. Invoking the barbarity of human sacrifice as an interpretative a priori, the tombs were immediately categorized as belonging to non-Greeks. The upcoming examination of the entire assemblage of one of these tombs, Tumulus XVII, coupled with the evidence from the more recent discovery at the Orthi Petra cemetery of Eleutherna (Crete), indicates that such an a-priori judgment is problematic. ${ }^{6}$ Irrespective of how our

\footnotetext{
4 In the realm of Greek myth, human sacrifice is famously associated with the Black Sea, and particularly the area in and around the Crimean Peninsula. As told in Euripides' tragedy Iphigeneia in Tauris, it is here that Iphigeneia - delivered by divine intervention from her own sacrificial death at Aulis - was installed, among barbarians, as priestess of the Taurian Artemis, whose cult required the sacrifice of foreigner arrivals to the land. For an illuminating discussion of the cult of Parthenos/Artemis in the Crimea and its broader significance, see now BRAUND, 2018, esp. pp. 15-60; add USTINOVA, 1999, pp. 98-99.

5 Among modern scholars, the most prominent proponent of this view is Pierre Bonnechere. See, for example, BONNECHERE, 2009. Following religious studies scholarship, HUGHES, 1991, pp. 1-12, outlines a terminological distinction between human sacrifice and ritual killing; accordingly, he tends to regard the slaughtering of human beings in funerary contexts as instances of the more general category of "ritual killing," since they lack the superhuman addressee (and cult thereof) required of "sacrifice" stricto sensu. Although I recognize the utility of this distinction, in this paper I shall speak of what HUGHES, 1991, passim, calls "funerary ritual killing" as "human sacrifice." What is meant by this term is sacrifices of the sphagion type, which consisted of lethal bloodshed performed on an occasional basis, without the requisite involvement of a priest, an altar, or preliminary rites, and not necessarily with an explicit superhuman recipient.

6 Due to its more recent discovery, the human sacrificial evidence from Orthi Petra was not available for consideration by HUGHES, 1991, pp. 13-48 and BONNECHERE, 1993. That said, BONNECHERE, 2009, p. $190 \mathrm{n}$. 3, subsequently judged the evidence to be a case of ritual killing but not sacrifice. His stated reason concerned not the ontological status of the recipient, but rather the manner in which the dead was dispatched (i.e. decapitation rather than throat-slitting). Yet, there is some iconographic and literary evidence, even if sparse and chronologically scattered, that suggests that sacrificial killings might occasionally entail the victim's beheading. For example, on a well-known Lucanian kalyx krater in Paris (400-375 BC; Cabinet des Médailles 422), the sphagion-type sacrifice that Odysseus performs for Teiresias in the Nekyia (cf. Hom. Od. 11.35 ) is represented as the decapitation of at least one of two animal victims: the ram. Cf. EKROTH, 2002, esp. pp. 174-175, with fig. 6, and 274-275 (with references). See also a red-figure stamnos now in Basel (Antikensammlung und Sammlung Ludwig BS477; circa 480 BC), on which a ram with an almost completely severed head appears beneath the dueling figures of Achilles and Hektor.
} 
ancient Greek literary sources may have characterized their own culture, archaeological excavations (particularly those conducted since the mid$20^{\text {th }}$ century) have identified a small set of temporally and geographically disparate contexts with material evidence tenably interpreted as the remains of rituals involving human sacrifice; therefore, human sacrifices seem to have been rare but nevertheless a historical reality, and were performed under special or extraordinary circumstances until at least the Late Archaic period.

Scholars generally agree that the evidence for human sacrifice is strong in a group of elite funerary monuments in the Northern Necropolis of Istros: Late Archaic tumuli XVII, XIX, and XII. However, in these cases, the tombs had been attributed, until the early 1990s, to non-Greek peoples. As a result, the site was omitted from Dennis Hughes' well-known study Human Sacrifice in Ancient Greece - although he was certainly aware of it and judged the evidence and the excavator's interpretation to be convincing (HUGHES, 1991, pp. 68-69). Likewise, in his study of Late Geometric Pyre A at Orthi Petra (Eleutherna), Nicholas Chr. Stampolidis briefly notes the site as an interesting parallel to human sacrifice in a funerary context, but it is not clear whether Stampolidis regards the burials as 'Greek' (STAMPOLIDIS, 1996, p. 170). ${ }^{7}$ The brevity of the discussion and his references to the earlier reports on the excavations, in which the barbarian classification was advanced, would suggest that he did not. ${ }^{8}$

The merits of the material evidence have never been met with any serious doubts since the tumuli's discovery. Yet, unlike the many alleged cases of Greek human sacrifice that have been scrutinized and questioned by scholars, especially Hughes and Pierre Bonnechere, here the principal issue concerns the omission of the tumuli of Istros from previous discussions on the archaeology of sacrificial killing in Greek antiquity. Scholarly research into the funerary customs of Greek colonists and native populations in the Black Sea has progressed considerably in the six decades since the Archaicera tumuli in Istros were first excavated, seeing the introduction of alternative interpretations of older finds in light of new discoveries and theoretical

7 Stampolidis accepts the excavator's identification of the victims as slaves.

8 He cites ALEXANDRESCU; EFTIMIE, 1959; and ALEXANDRESCU, 1965a. ALEXANDRESCU, 1994 perhaps appeared too late for consultation; in it, the author revisits the evidence over three decades later and reverses his position, arguing that the burials belonged to Greeks. As Stampolidis did in the case of Pyre A, Alexandrescu interprets the evidence with reference to the funeral of Patroklos and argues that the corresponding elements in the text and archaeology suggest a deliberate imitation of epic behavior. 
models. Through this process, a great deal of research has been conducted regarding the identity of the entombed individuals. Although for decades researchers regarded the Istrian tumuli as non-Greek constructions, a new wave of scholarship, initiated by the excavator's own interpretative volteface, has demonstrated that these burials should be resituated within a Greek or colonial hybrid cultural ambit.

\section{Excavation of the Late Archaic Tumuli in the Northern Necropolis}

In 1955, a Romanian team of archaeologists led by Petre Alexandrescu embarked on a seven-year campaign of excavations in the vast tumular necropolis to the west and north of Istros, a Milesian colony on the western coast of the Black Sea, in the region of Dobrudja. These activities resulted in the exploration of some 40 tumuli, of which 34 were subsequently published in 1966 in the second volume of the Histria series (cf. ALEXANDRESCU, 1966, esp. pp. 163-183 with French summary on pp. 409-422) (Fig. 1). ${ }^{9}$ The oldest of these tumuli, unearthed between 1957 and 1959 , date to the latter half of the sixth century BC and were concentrated in the southeastern region of the Northern Necropolis, in what is now a marshy peninsula surrounded to the west by Lake Istria and to the east by Lake Sinoe. These tumuli, numbered XII, XVII, XIX, and XX, were special not only because of their relative antiquity, but also because of the unusual finds concealed within them: the unburnt skeletal remains of horses and, in three of these tombs, of humans, who seem to have been slaughtered or deposited en masse at the grave as an offering to the deceased (ALEXANDRESCU;

9 The following discussion of the finds is drawn largely from the report cited above. The four Archaicera tumuli were preliminarily published in ALEXANDRESCU; EFTIMIE, 1959; and in the annual reports on the excavation: ALEXANDRESCU, 1959, pp. 289-299; ALEXANDRESCU, 1961, pp. 261-264; and ALEXANDRESCU; VÎLCEANU, 1962, pp. 417-418. 
EFTIMIE, 1959, p. 146). ${ }^{10}$ The tombs containing the skeletons of human victims all belong to Alexandrescu's JAa I (Tumuli XIX, XII) and JAa II (Tumulus XVII) classifications. Both types consist of primary cremations carried out directly on a prepared surface with an earthen tumulus piled on the remains of the pyre; the latter type also includes a circular combustion pit. ${ }^{11}$ These types of tombs constitute the oldest in his typological series and are confined chronologically to the second half of the sixth century (ALEXANDRESCU, 1965b, p. 174).

\section{Fig. 1 - Chronological site plan of the tumular necropolis at Istros, showing the vicinity of Late Archaic Tumuli XVII, XIX, and XII (550-490 BC); accompanied by a satellite image of its northern section.}
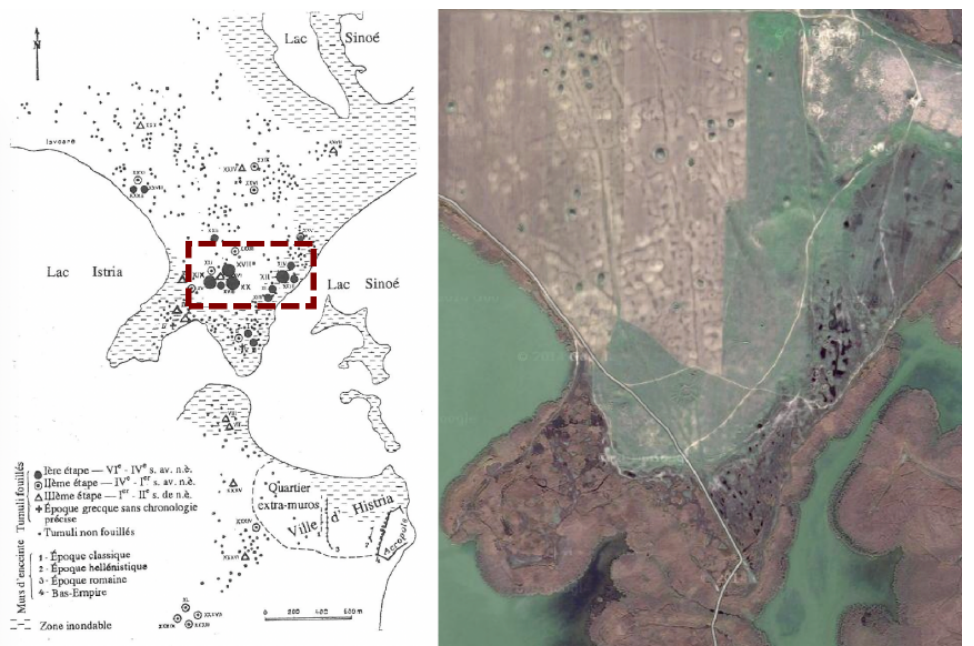

Credit: ALEXANDRESCU 1966, p. 138 fig. 11, with dashed box added by author (left); Google Earth (right).

10 In the final report, ALEXANDRESCU, 1966, p. 149, the excavator associates the unpublished tomb XLII with the above tombs from the perspective of ritual. The only find from the excavation of this tomb that was discussed is a cup imitating the Class of Agora P 10359, which would seem to date the burial generally to the first quarter of the $5^{\text {th }}$ century BC, i.e. the youngest in the proposed group of tombs. Cf. ALEXANDRESCU, 1978 b, pp. 118-119 (cat. no. 772), with fig. 32 .

11 On the typology of Istrian cremation burials, see esp. ALEXANDRESCU, 1965b; also, ALEXANDRESCU, 1966, pp. 247-267 and 416 (French); ALEXANDRESCU, 1971. In his typology, Alexandrescu does not distinguish between mantles that enclose the peripheral ditch (as in XVII) and platform and those that do not (ex. XIX). 
The date of the colony's foundation has been assigned approximately to the third quarter of the seventh century BC, which places it among the most ancient Greek settlements in the Black Sea area. Istros does not appear to have been established in an area previously inhabited by local populations; native settlements were situated further inland (AVRAM, 2006, pp. 59-62). ${ }^{12}$ While no tombs dating from first Archaic decades of the settlement have yet been identified in the necropolis, hundreds - and by some counts thousands of tumuli remain unexplored and others are thought to have been submerged or eroded by marine incursions and shifting coastlines (ALEXANDRESCU, 1978a; ALEXANDRESCU, 1966, pp. 137-140). ${ }^{13}$ Although comparatively few in number, the excavated tumuli suggest that, during the nearly eight centuries of the cemetery's use, cremation remained the predominant burial method (ALEXANDRESCU, 1965b, pp. 163-164). According to Alexandrescu, it is only in the fifth century that tombs with "a purely Greek character" appear, with the JAaV type tumulus, which contained a primary cremation constructed entirely inside an oval pit with the incinerated remains left in situ $\left(5^{\text {th }}\right.$ cent. BC $-2^{\text {nd }}$ cent. CE) (ibid., p. 183). However, as we will see in the discussion that follows, one should question the non-Greek characterization of the earliest tombs - which was predicated on a scarcity of documented Greek parallels and several non-Greek analogues that differ, however, in significant ritual elements (such as the placement of burnt bones in a receptacle) or are much more recent (ibid., pp. 174-180). Moreover, it seems rather unlikely that the Istrians would only later abruptly begin to bury their dead in an area that had been used by indigenous people and was only a short distance from the city center. We will return to this problem after considering the evidence from the Archaic tombs themselves.

Among the Archaic burial mounds, Tumulus XIX provides the best-preserved evidence for their construction and the rites practiced during the funeral (ALEXANDRESCU, 1994, p. 16). The burials were primary cremations, that is, the mounds were raised on the exact spot of the funerary pyre. In their core were the carbonized remains of these pyres, erected on a

12 See also AVRAM, 2003 for a detailed discussion of the city's history, organization, and institutions.

13 ALEXANDRESCU, 1963, p. 258 n. 2 believes that such tumuli exist and that they just have not yet been excavated or were submerged with the shifting of the coastline. Excavation in the Northern Necropolis was resumed in the summer of 2015 under the direction of Mircea Angelescu in the area locally known as Movilele Dese, during which a Roman imperial-era tumulus (no. N-1-413; $2^{\text {nd }}-3^{\text {rd }}$ cent. AD) was excavated; due to lack of funding, however, the project was suspended (M. Angelescu, personal comm. 17 January 2016). 
flat earthen platform laid over the virgin soil (composed of loess or sand) and whose centers were reddened and hardened by intense exposure to fire. ${ }^{14}$ Based on the remains - organic and artifactual - it was determined that the deceased were placed north-south on a rectangular pyre constructed from rows of wooden planks with parallel spacing, stacked in perpendicularly alternating levels to form a grid (Fig. 2). The corpse was surrounded by offerings. During the cremation ceremony, it also appears also that ceramic objects were cast on the pyre, among them vases used for drinking. This suggests that the ritual included some form of drinking activity: group drinking (wine?), libations, or both. After the pyre burned, the burnt remains were either left untouched or carefully amassed at the center of the pyre (ALEXANDRESCU, 1994, pp. 19-20). This stage could also involve the presentation of another round of offerings (ritually broken?) (ALEXANDRESCU, 1965b, pp. 165-166). ${ }^{15}$ The area of the cremation was then concealed underneath a mantle of earth, often consisting of two layers of soil. In addition to the elevated platform, on which the above activities transpired, the space of the tomb was inscribed within a trench of a consistently circular shape but with varying dimensions (width: 0.70-1.70 m; depth: around one-half meter). ${ }^{16}$ The trench could be hidden under the layers of the tumulus, although this was not always done. It is in these trenches and along the inner perimeter of the cremation platforms that unburned skeletal remains of the human and equine victims were found.

14 Based on the well-preserved remains of the pyre from Tumulus XIX, the pyres were nearly square $(3.0 \mathrm{x}$ $2.6 \mathrm{~m}$ ) and composed of regularly spaced timbers running parallel to one another and alternating directions at each level to form a grid, analogous to what Stampolidis observed at Pyres A and B in the Orthi Petra cemetery of Eleutherna. For the structure of the Orthi Petra pyres cf. STAMPOLIDIS, 1996, p. 29.

15 That there were two separate rounds of offerings made to the dead (first during the cremation, and second before the erection of the tumulus) can be discerned on the presence or lack of traces of burning on their surfaces. Only the unburnt offerings located in the area of the pyre itself can be securely associated with this second stage. Others could have been deposited at any point in the cremation and burial ritual.

16 If part of the earth removed in cutting these trenches was used to create the central podium, as ALEXANDRESCU; EFTIMIE, 1959, p. 145, propose as a possibility, this would suggest that the entire plan of the tomb was realized at once. 
Fig. 2 - Drawing of the in-situ remains of the funerary pyre erected on the cremation platform of Tumulus XIX.

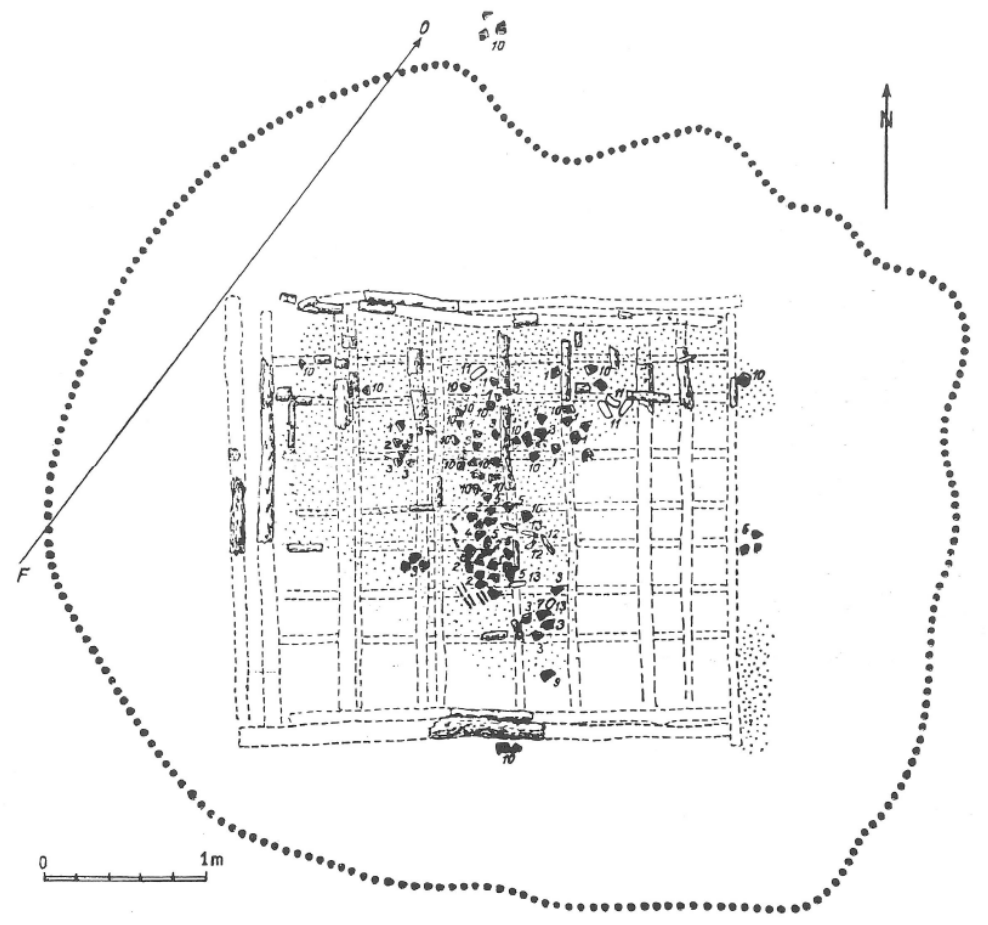

Credit: ALEXANDRESCU 1966, p. 152 fig. 18

\section{Tumulus XVII}

The clearest and most impressive case of human sacrifice performed in the context of the cremation burial is offered by Tumulus XVII (550-525 BC; diameter: 11.0 m; height: 1.50 m; Figs. 3-5) (ALEXANDRESCU, 1966, 
pp. 146-150; ALEXANDRESCU; EFTIMIE, 1959, pp. 144-149). Here, the unburned bones of three humans and four horses were found dispersed around the inner edge of the cremation platform and inside the peripheral trench. The humans generally occupied the western half of the tumulus and the horses the eastern half. ${ }^{17}$ The mantle of the tumulus consisted of two separate layers of brown earth, which hid a circular cremation platform (height: 25$30 \mathrm{~cm}$ ), with much of its surface area $\left(\right.$ circa $\left.28 \mathrm{~m}^{2}\right)$ intensely hardened by fire (ALEXANDRESCU, 1966, pp. 146-147; ALEXANDRESCU; EFTIMIE, 1959 , p. 145). A shallow pit was dug in its center. In and above the pit, as well as just outside its southwestern edge, the incinerated remains from the pyre were collected: small pieces of calcined human bone, charcoal, and the burnt fragment of an unguent container (lydion; XVII/1). These materials are another attestation of the intensity of the fire. Several unburned fragments belonging to additional artifacts were found scattered over the surface of the cremation platform, most of them within the area of fire-hardened earth, and with a marked concentration to the immediate east and northeast of the central pit: an Attic black-figure band cup with a frieze of bulls and lions (XVII/2); a Late Corinthian skyphos decorated along its base with a wolf-tooth pattern (XVII/3); an 'Ionian' oinochoe of quotidian use (XVII/4); a hand-made pot decorated with an alveolar cordon (XVII/5), an amphora (XVII/6); and an alabastron made of alabaster (XVII/7) (ALEXANDRESCU, 1966, p. 149; ALEXANDRESCU; EFTIMIE, 1959, p. 146).${ }^{18}$ Although sherds belonging to each of these objects were retrieved from within the zone of baked earth, the absence of carbonization on their surfaces indicates that they were deposited after the flames of the pyre had died down or were extinguished; thus, they are interpreted as additional offerings to the deceased or as objects deposited after use in a post-cremation rite.

17 With the exception of the skeletons of human 3 and horse 4, which were found close together in the south section of the trench: the human was positioned more to the east than the horse.

18 The alabastron is not mentioned in the preliminary report. 
Fig. 3 - Stratigraphic section drawing showing the relative positions of Tumuli XVI, XVII, XVIII, and XIX.

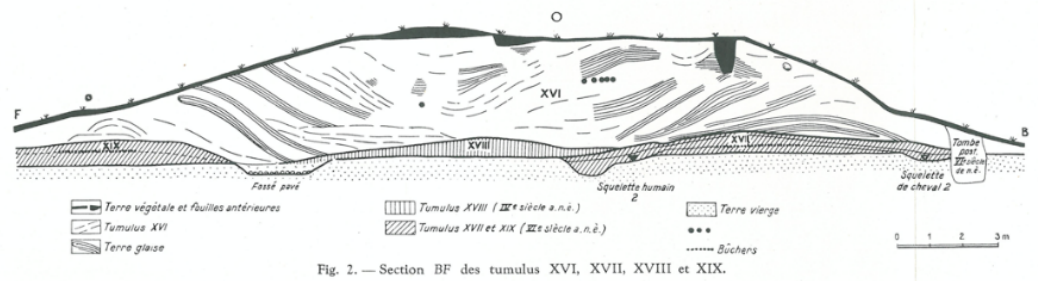

Credit: ALEXANDRESCU; EFTIMIE 1959, fig. 2.

Fig. 4 - Plan and stratigraphic section drawing of Tumulus XVII and its cremation platform (550-525 $\mathrm{BC})$.

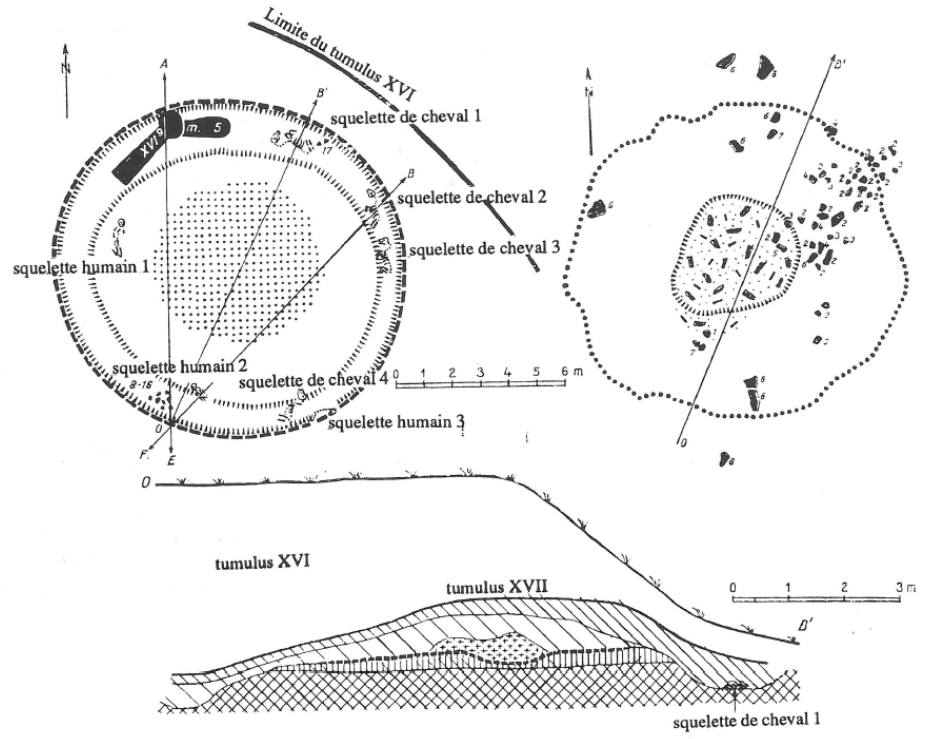

Credit: ALEXANDRESCU 1966, p. 143 fig. 14. 
Two of the human skeletons were also found on top of the cremation platform, though along its margin - viz. outside the circular area of firehardened earth. That each of these human beings was violently dispatched is best illustrated by the posture of skeleton 1 (Fig. 5). This skeleton was found on the west-northwest edge of the platform, lying on the left side and facing the direction of the pyre, with the head pulled back to expose the neck, the arms drawn behind the back in position that indicates binding, and the lower legs bent at an extreme angle behind the thighs, bringing the feet close to the pelvis (ALEXANDRESCU, 1994, p. 23; ALEXANDRESCU, 1966, pp. 147-148; ALEXANDRESCU; EFTIMIE, 1959, p. 148). The skeleton of the second individual was deposited in a different, but equally abnormal position, which also suggests binding and forced execution. It was found at the southsouthwest end of the platform, facing away from the pyre. The individual's skeleton was lying face down in a compacted position, with the arms together and pressed tightly against the chest and the knees drawn into the ribs and the lower legs bent underneath toward the pelvis (ALEXANDRESCU, 1966, p. 148; ALEXANDRESCU; EFTIMIE, 1959, p. 148). The victim therefore appears to have had their arms fettered in front of the body and was forced to kneel before being murdered. After the act was committed, the victim fell forward or was pushed in that direction. In both instances the legs of the first and second individual could also have been bound (ALEXANDRESCU, 1994, p. 23). The hypothesis of the excavator is that the individuals were naked at the time of their death, as no sartorial accessories (e.g. fibulae) were uncovered. While we cannot rule out this possibility, it should be noted that the area of the funeral pyre also did not produce any such objects - even though we can reasonably assume, based on the contemporary iconographic repertoire, that the honored dead would have been clothed and/or shrouded. 
Fig. 5 - Excavation photographs and scaled drawing of the in-situ positions of human Skeletons 1 and 2 , discovered respectively along the WNW and the SSW edge of the cremation platform.
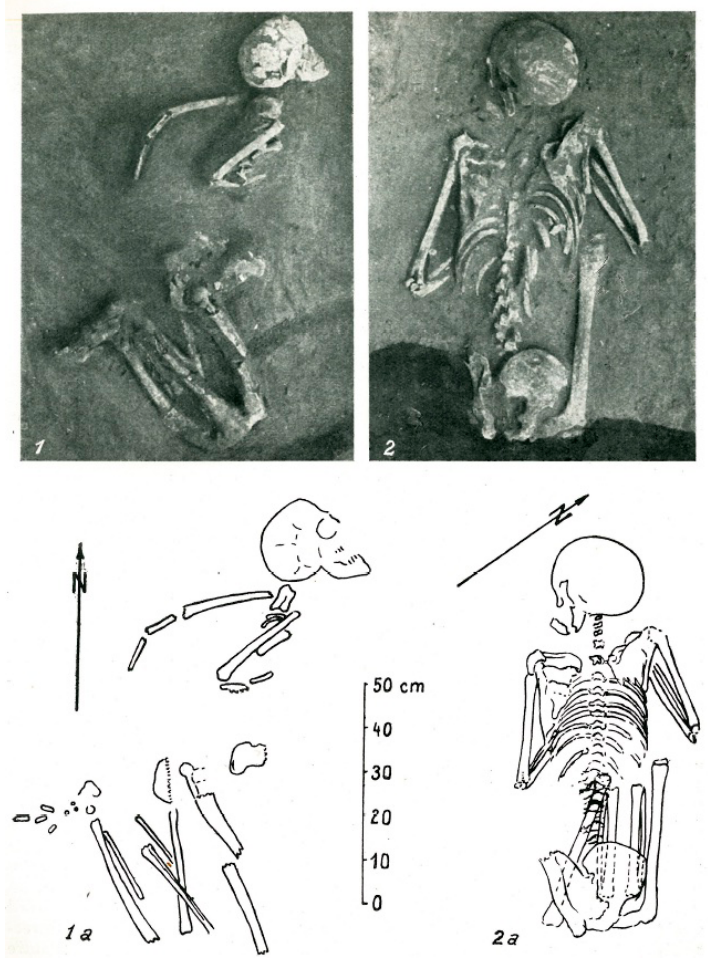

Credit: ALEXANDRESCU; EFTIMIE 1959, fig. 6.

The temporal relationship between these killings and the cremation of the deceased on the pyre cannot be precisely determined. No portion of the victims' skeletal remains were burned - unlike the case of the ritually decapitated man discovered at the northwest margin of Pyre A at Orthi Petra, whose first thoracic vertebra was exposed after the act of beheading and subsequently charred by the fire of the pyre. In the case of the victim at Pyre A, the burning of the exposed interior surface of the vertebra demonstrates with uncommon certainty that the killing was performed before the pyre was lit (STAMPOLIDIS, 1996, pp. 32-34, 
85-87). The timing of the Istrian victims' deaths may have been similar; however, the placement of their corpses outside the zone affected by the flames of the pyre leaves us without clear chronological evidence. The victims could also have been killed in the process of the cremation or after the pyre had died down or been extinguished. The only certain thing is that the victims' corpses were positioned on the platform before it was sealed within the earthen layers of the tumulus. After this point, they remained undisturbed until their excavation. Before proceeding with our analysis, it is worth noting that the extreme curvature of the spine of the male victim slaughtered next to Pyre A at Orthi Petra suggests that the individual had his arms and legs bound behind his back in a manner similar to skeleton 1 in Tumulus XVII. That said, the skeletal remains of the victim at Pyre A bespeak the performance of a different series of violent actions, including decapitation and, as it seems, bodily mutilation (ibid., p. 77 [McGeorge]). From the extremity of this violence we may infer a negative emotional background and one of a decidedly greater intensity than at Istros.

The cremation platform was surrounded by a circular ditch, which was carved into the virgin loess. The remains of the third human being (skeleton 3 ) and the four horses were situated inside this ditch. Skeleton 3 was positioned in its southeast sector, along the outer scarp. Although the skeleton's bones are poorly preserved, its posture is akin to that of skeleton 1 (ALEXANDRESCU, 1994, p. 21; ALEXANDRESCU; EFTIMIE, 1959, p. 148). ${ }^{19}$ Therefore, this individual also seems to have been bound and slaughtered. Three of the horse skeletons were uncovered intact in the northeast quarter of the trench. The skeleton of horse 1 was, unlike the others, turned away from the center of the tumulus. Deposited near the bones of the hind legs was a fragmented handmade vase (a jar?; XVII/17) (ALEXANDRESCU, 1994, p. 23). ${ }^{20}$ The fourth horse, located close by human skeleton 3 , was in a poor state of preservation; it appears to have been butchered.

None of the horses were found with riding or driving equipment. Only one other area of the ditch, the southwest quarter, yielded a cluster of nine fragmented and incomplete vessels associated with perfume and the preparation and consumption of food and drink: drinking - an

19 Based on the plan of the tumulus (cf. Fig. 4), the individual faced away from the pyre; cf. ALEXANDRESCU, 1966, p. 147 fig. 15.

20 In the excavation report, ALEXANDRESCU, 1966, p. 146, incorrectly lists the find spot as "underneath the skeleton of horse 2" (and which contradicts the plan given in the same report at p. 147 fig. 15). 
undecorated Attic black-figure lip cup (XVII/8); a Fikellura-style amphora (XVII/9); a locally-made trefoil oinochoe (XVII/11); a 'miniature' blackfigure krater (XVII/13); and two amphorae (XVII/14-15); cooking and dining - a kitchen pot (chytra; XVII/12); and a locally made lekanis with vertical handles (XVII/10); unguents - a second alabaster alabastron (XVII/16) (ALEXANDRESCU, 1966, pp. 149-150 with pls. 69 and 85; ALEXANDRESCU; EFTIMIE, 1959, p. 148). ${ }^{21}$ These objects were deposited, to judge by the plan of the tumulus, approximately one meter to the east of human skeleton 2 . While the tumular mantle also covers the area of the ditch, its two layers are not evenly spread over the entire surface of the tomb. According to the stratigraphy of profile O-B', the lower layer of the mantle does not extend to the region of the trench where the horse skeleton 1 was deposited; instead, this area is covered only by the upper layer. The lower layer, however, does appear to cover the part of the ditch where the assemblage of broken vessels was brought to light. ${ }^{22}$

The diagnostic ceramics recovered from the circular trench and the cremation platform are contemporary and include some objects of the same type, notably the Little-Master cups and the alabastra. Furthermore, the stratigraphic profiles cut through the tumulus indicate that the pyre and the trench were generally covered with the same layers of soil, which are internally consistent throughout (ALEXANDRESCU; EFTIMIE, 1959, pp. 148-149). These two facts suggest that the human beings and horses were killed and deposited in the context of the funerary ritual, at some point between the construction of the cremation platform and the raising of the mound. In the Roman Imperial Period, the tumulus would be included inside an even larger tumulus (the so-called 'Belvedere tumulus'; a cenotaph), into which numerous graves would be cut in the sixth century AD. One of them, the catacomb-like inhumation grave $\mathrm{XVI}^{9}$ (late $6^{\text {th }}$ cent.), was sunk into the part of the Belvedere tumulus overlying the north-northwest section of the peripheral ditch of tumulus XVII. ${ }^{23}$ Its considerable depth, $4.70 \mathrm{~m}$, resulted

21 Cf. ALEXANDRESCU, 1978b, p. 53 (cat. no. $158=$ XVII/9); p. 108 (cat. $701=$ XVII/10), with fig. 25; p. 100 (cat. no. $649=$ XVII/11); and p. 124 (cat. no. $819=$ XVII/12), with pl. 71.

22 One other profile cut through the tumulus (F-B), which happened to cross over human skeleton 2 and horse skeleton 2, provided further evidence that these depositions belong to the same chronological frame as the cremation. Cf. ALEXANDRESCU; EFTIMIE, 1959, pp. 148-149, with figs. 2-3 and 5.

23 Another sixth-century grave $\left(\mathrm{XVI}^{8}\right)$ was dug in proximity to Tumulus XVII, though just outside the northeast limits of the peripheral ditch. For both graves, see ALEXANDRESCU, 1966, pp. 227-228, with p. 147 fig. 15 and p. 205 fig. 45; ALEXANDRESCU, 1961, p. 258, with fig. 24-25 and p. 261 pl. 8. 
in the disturbance of the fill layers in this portion of the ditch. Just to the east of this grave, also inside the peripheral ditch, was another burial shaft (M5). But, unlike the previous tomb, M5 lay beneath the layers belonging to the Belvedere Tumulus; its shaft is carved into the fill of Tumulus XVII. M5 was a 'flat' inhumation grave containing several artifacts, which assign it to the mid-fourth century BC (ALEXANDRESCU, 1966, p. 231). ${ }^{24}$ Fortunately, these intrusions into the fill layers of Tumulus XVII's peripheral ditch were limited in scope; they do not interfere with the stratigraphic and contextual integrity of any of the aforementioned funerary deposits.

What is more, the outermost edge of the mantle belonging to the Classical-era Tumulus XVIII (circa 400 BC) overlaps the fill layer that covers the southwest quarter of Tumulus XVII's peripheral ditch. Even so, the people who constructed Tumulus XVIII respected the position of the existing tomb mound, since the fill for Tumulus XVIII stops short of obscuring the area of Tumulus XVII that would then have been visible above ground; the filling over Tumulus XVII's peripheral ditch would have been nearly flush with the ancient ground level (cf. ALEXANDRESCU, 1966, pp. 176-177). ${ }^{25}$ The discovery of these Classical-era tombs in and above the ditch of Tumulus XVII shows that this area of the necropolis remained in use after the Archaic period. The consistency of the fill layers in the peripheral trench and the absence of any later material therein is further evidence that Tumulus XVII constitutes a chronologically unitary context.

While the bodies of the three human victims were contained within the tumulus, they were not, properly speaking, accorded a burial. Like the decapitated man from Pyre A at Eleutherna, no object seems to have been deposited with the victims as a personal item or gift. All the small finds are rather associated with the cremated deceased, either as burial offerings

24 Tomb M5 is one of a small group of 'flat tombs' that were excavated in and around the Belvedere tumulus, ranging in date from the sixth and third centuries BC; for which see ALEXANDRESCU, 1966, pp. 229-232. 25 See further ALEXANDRESCU, 1966, p. 203 fig. 44 and p. 205 fig. 45. ALEXANDRESCU, 1961, p. 261 pl. VIII and p. 262 fig. 26; and ALEXANDRESCU; EFTIMIE, 1959, p. 145 fig. 2-4 for plans and profiles H-D and F-B of the 'Belvedere Tumulus,' which shows the respective stratigraphic situations of the underlying Tumuli XVII and XVIII. Like these tumuli, the Classical-era flat graves M4 and M5 also respected the elevated zone of the tomb; even if we grant the possibility that the cenotaph M4 ( $5^{\text {th }}$ cent. BC) was originally covered with barrow (a possibility the authors admit), its position relative to Tumulus XIX would suggest that it, too, respected the boundaries of existing mounds; indeed, its central location between Tumulus XIX and the Late Classical-Early Hellenistic Tumulus XXI may evince the existence of a circular mound. For the 'flat' graves and their relative locations within the Belvedere Tumulus, see ALEXANDRESCU, 1966, pp. 230-231 with fig. 44. 
to him or her, or as objects utilized in the funerary rites (such as communal feasting and libations). Unfortunately, the skeletal remains - both of the cremated individual and of the unburnt victims - were never submitted to forensic examination. Because of this, we lack critical information about their identities, e.g. their sex, age, health, origins, and whether their bones exhibit signs of peri-mortem trauma. The physical anthropologist affiliated with the excavation, Dardu Nicolăescu-Plopșor, only notes that the highly irregular and unnatural postures of the peripheral skeletal deposits are redolent of binding (NICOLĂESCU-PLOPŞOR, 1959, pp. 165, 170). ${ }^{26}$ In the absence of other evidence, like a serviceable weapon, he leaves open the matter of how they were killed (namely, buried alive or mortally wounded: NICOLĂESCU-PLOPȘOR, 1959, pp. 168, 170, 178). The fact that these victims lacked accompanying grave goods, were not cremated like the dead in the center of the platform, and were found in unusual postures that evoke captivity at the time of their death is, nevertheless, strong evidence that they were not among the honored dead. Rather, the individuals were conveyed to the site of the cremation and killed at some point before the conclusion of the funeral process, with the mounding of the tumulus. From the standpoint of the timing of these ritualized killings, no further specificity can be gleaned from the available evidence.

It is tempting to see the four slaughtered horses as a team; but their lack of equipment and scattered disposition around the ditch, in addition to the apparently different treatment of the body of one (butchering), militates strongly against such an identification. However, it is not inconceivable that they were indexically associated with a quadriga and thus another means to associate the dead with the generation of heroes. ${ }^{27}$ Whether or not the respective killings of the horses and human beings were performed at once or in succession, the choreographic dimension of the sacrificial rites would have necessitated the active involvement of several people - just to keep each victim in their designated place. We will return momentarily to the notion of 'epic' imitation/emulation, particularly as it pertains to the interpretative trope of Patroklos' funeral.

26 Even with the publication of the final report on the excavations, the bones remained unstudied: NICOLĂESCU-PLOPȘOR,1966, pp. 372-373.

27 For similar lines of interpretation with respect to elite tombs in Cyprus, which draw upon the Homeric account of Patroklos' funeral, see KARAGEORGHIS, 2003, pp. 344-345 and pp. 347-348; KARAGEORGHIS, 1965, pp. 310 and 312; KARAGEORGHIS, 1963; and promoted by COLDSTREAM, 2003, pp. 349-350; heavily qualified in BLACKWELL, 2010. 


\section{Initial Interpretation of the Material Traces of Human Sacrifice within Tumulus XVII}

When Alexandrescu and Eftimie first set out to make sense of the evidence from the Late Archaic tumuli, they were confronted with a lack of archaeological precedent for these burials (ALEXANDRESCU; EFTIMIE, 1959, p. 159). The blood sacrifices of human beings, suggested by the skeletal evidence and its stratigraphic position within the tumuli, had never been found at any Romanian site dating to the sixth century BC; and the human sacrifices documented in Scythian contexts were dissimilar in form (ibid., pp. 160-161). ${ }^{28}$ Rather than being retainers, intended to accompany the deceased to the afterlife, the authors proposed that the victims were instead executed in an ostentatiously violent fashion as 'expiatory' sacrifices, "destiné[s] peut-être à venger la mort de personnes ayant péri elles-mêmes par violence" (ibid., p. 161). Curiously, they go on to cite the funeral of Patroklos (Hom. Il. 23.105-257) as a loose literary parallel for this sort of ritualized killing, but do not ultimately propose a Greek identification for the observed rites. As at Pyre A in Eleutherna, we lack any direct forensic evidence that the deaths of the cremated deceased were violent. Despite the proximity of the tumuli to the city and their overwhelmingly Greek-made contents, ${ }^{29}$ Alexandrescu and Eftimie contended that the burials must have belonged to barbarians (i.e. local chieftains), since "le rite si primitif des sacrifices humains est incompatible avec le degré qu'avait atteint à cette époque la civilisation hellène" (ibid., p. 162, emphasis mine).

After excluding a Greek attribution based on this judgment, the excavators attempt to find another ethnic identification (Getic/Thracian) by adducing a number of archaeological comparisons, none of which date to

28 The authors identify a number of distinctions between the Istrian victims and Scythian 'retainers', for instance, the Archaic tumuli at Istros lack any evidence of care for the victims; the victims lack personal items, which might suggest that they were killed and deposited nude; and they were not given the same type of burial as the deceased. Rather than accompanying the dead to the afterlife as attendants, the evidence suggests to them that the significance of the killings consisted in the violence and bloodshed itself. The whole act was meant to expend human life, perhaps in order to avenge or appease the dead. On Scythian elite burials see IVANTCHIK, 2011.

29 It was not the habit of Thracians prior to the Hellenistic period to site their tombs nearby zones of habitation; cf. RABADJIEV, 2016, pp. 281-311, esp. p. 284: "the space for the dead in Thrace was in the natural landscape, not close to the human one." 
the same period of time or exhibit a similar collection of features found in the Istrian tumuli. In successive presentations of the evidence Alexandrescu elaborated on this reading. ${ }^{30}$ All the while, the presence of human sacrifices, as the author admits in the summary to the official excavation report on the tumuli, remained "un facteur décisif dans nos tentatives d'attribution ethnique de ces tombes anciennes en dirigeant notre attention sur les populations établies dans le voisinage d'Histria" (ALEXANDRESCU, 1966, p. 421) ${ }^{31}$

Alexandrescu's initial interpretation is thus predicated upon the assumption that the tumuli should be attributed to non-Greeks because the sacrificial slaughter of humans is 'primitive' and thus inconsistent with the more 'advanced' Greek culture. Although geographically and temporally removed from Istros, the more recent and undeniable evidence of the sacrifice of an adult man from Pyre A at Orthi Petra (circa 700 BC) shows that the violent, ritual murders of individuals at the side of a funerary pyre could be performed within Greek communities, and not just ones enveloped in the mists of myth or remote prehistory. ${ }^{32}$

30 ALEXANDRESCU, 1963, p. 261, where the group of tumuli with peripheral offerings are deemed firmly "de caractère indiscutablement autochtone"; ALEXANDRESCU, 1965a, p. 339; ALEXANDRESCU, 1966, p. 421. 31 This reasoning was first given in the initial report on Tumuli XVII and XIX: ALEXANDRESCU; EFTIMIE, 1959, p. 162. The authors believe that Homer is a reflection of Mycenaean times, when such practices were done (and of which they believe there is isolated evidence), but that this act had long since been abandoned.

32 Additional corroboration has also been sought in the cemeteries of Cypriot cities, for example, in Salamis Chamber Tomb 2. Here, too, the excavator, Vassos Karageorghis, saw material reflections of - or potential inspiration for - the funerary behaviors described in epic literature (most notably the funeral of Patroklos); see supra n. 26. Incidentally, Greek prehistory is not without proposed archaeological evidence for human sacrifice: One of the most recent and compelling discoveries of this nature was made in the last decade, during the excavations of the Mycenaean-era palatial complex of Kydonia (Crete). Here, within a colonnaded courtyard and in proximity to an altar-like structure, excavators uncovered a dense, commingled deposit of disarticulated skeletal remains belonging to a teenage human female and 49 domesticated animals (overwhelmingly ovicaprids and female). The stratigraphy of the deposit strongly suggests that the killing of these 50 individuals and their placement in a shallow, purpose-made recess in the courtyard's floor was contemporary, and that these actions were performed as a ritual response to a highly destructive seismic episode (dating to 1300-1250 BC/LM IIIB). On this find, see now ANDREADAKI-VLAZAKI, 2015 (synthetic analysis); MCGEORGE, 2015 (human remains); and MYLONA, 2015 (faunal remains). 


\section{The Interpretation Revisited}

Three decades after the discoveries, Alexandrescu revisited the evidence, noting once again the general parallels between the funeral of Patroklos and the Archaic tumular burials at Istros (ALEXANDRESCU, 1994, p. 29): ${ }^{33}$ among them, construction of a funerary pyre on a prepared ground, offerings of horses and humans (though not their incineration!), separation of the body of the deceased from these offerings, pouring of libations, extinction of the pyre with wine, circumscription of the tomb area, and the erection thereupon of an earthen tumulus. However, this time, Alexandrescu reversed his initial opinion, arguing particularly on the basis of related finds from Cyprus that epic imitation supplies a sufficient explanation for these burials (ibid.). ${ }^{34}$ While, as in Eleutherna, there are important discrepancies between text and archaeology that complicate any case for direct correspondence, the resonances with the funerary rites as narrated in Homeric epic cannot be entirely ruled out. One of these connections, human sacrifice, is, to my knowledge, not attested in any contemporary Thracian necropolis (cf. SIMION, 1998, p. 169; SÎRBU, 1993 [1997], p. 196). Since Alexandrescu's 1994 article, scholarly opinion has swung in this new interpretative direction, with various nuances added in light of research on the complexity of ethnic identity in the pre-Classical era (DAMYANOV, 2012, pp. 42-43; DONNELLAN, 2011; DONNELLAN, 2004-2005, esp. pp. 201-217; HJARL PETERSEN, 2010, pp. 117-118; cf. HALL, 2002, esp. pp. 104-111)..$^{35}$

The tumuli of Istros are now conceivable within a Greek colonial context, thanks to the excavation of the tumuli in the northwest vicinity of the settlement identified as the Ionian colony of Orgame. The most notable among them is the 'heroon' (tomb T-A95; third quarter of the seventh cent. BC; Fig. 6) (LUNGU, 2000-2001; LUNGU, 2002; LUNGU, 2007, pp. 346-348; LUNGU, 2008, pp. 155-162; LUNGU, 2017). ${ }^{36}$ The 'heroon', the

33 And recently reprised by LUNGU, 2008, esp. pp. 154-155.

34 In so doing, he references the skeletal remains from the dromos of Tomb 2 at Salamis, the principal publication of which is KARAGEORGHIS, 1967, pp. 6-24.

35 One exception is OPPERMANN, 2004, pp. 22-36, who retains the original Getic/Thracian identification, while admitting that the Greek attribution cannot be removed from consideration.

36 As DAMYANOV, 2005 , p. 88 , notes, the discovery of the $7^{\text {th }}$-century tumuli at Orgame helped dispel doubts over the Greek affiliation of the earliest tumular burials at Istros. Like Istros, Orgame seems to have been founded in a then uninhabited area. 
alleged tomb of a revered oikistic figure, is interesting because not only does it date more than one half century before any excavated tumulus at Istros, but it also comes from a West Pontic Greek - perhaps also Milesian - context. The tumulus was much more monumental in size than any other in the region (more than 42.0 meters wide). It was raised over the site of the funerary pyre on which the deceased was cremated. In the center of the tumulus were the incinerated remains of the wooden pyre, rectangular in plan, which had been built over a shallow cremation pit $(60 \mathrm{~cm}$ deep; $\mathrm{cf}$. that of Tumulus XVII at Istros); the intensity of the fire led to the baking of the surrounding earth to a maximum diameter of 8.0 meters. The area of the pyre was covered with a 30 -centimeter thick layer of ash, burnt bone, and fragmentary ceramics. The cremation pit was covered with a pile of burnt stones, which were either used in some manner during the burning of the pyre or were used to help extinguish the pyre. Outside the eastern side of the cremation pit was another burned area with the remains of animal offerings in the form of incinerated animal bones. Few human bones, identified as belonging to a man, were recovered from the cremation pit, which led the excavators to speculate that they were collected and stored in a special container that may have been illicitly obtained from one of the numerous pits that marred the tumulus. Among the ceramics found inside the tomb, two Chian amphorae and a Samian band cup helped establish the chronology of the burial. Non-ceramic objects are rare, limited to a fragmentary bronze object and a small undecorated gold sheet.

Fig. 6 - Aerial photograph of the excavation of the 'Heroon' (Tumulus T-A95) at Orgame (third quarter of the 7th cent. BC). Image courtesy of Vasilica Lungu.

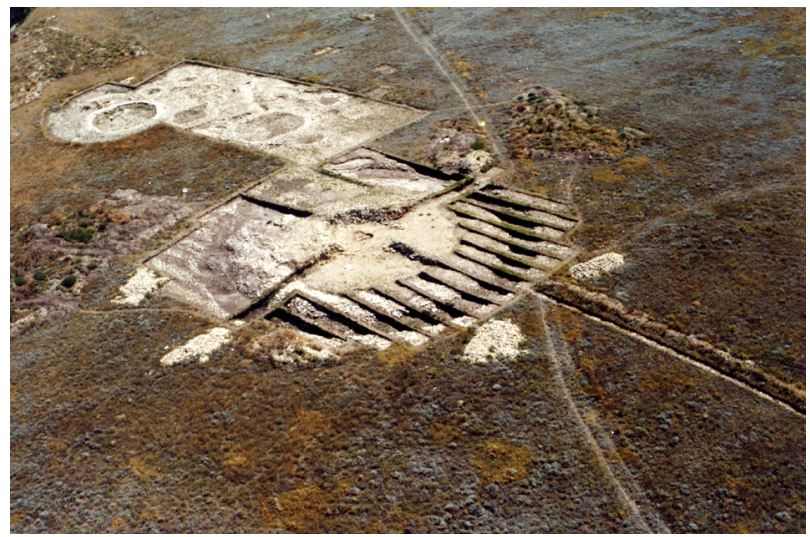


The cremation zone was surrounded by a thick stone ring (up to $7.0 \mathrm{~m}$ wide at the base) and enclosed within a mantle of earth and stones (height: circa $1.25 \mathrm{~m}$ ) (LUNGU, 2000-2001, p. 173). The exterior of this stone enceinte was surrounded by a discontinuous peripheral trench that was carved into the bedrock at a depth ranging between $0.1 \mathrm{~m}$ and 1.35 $\mathrm{m}$. It evidently remained exposed and frequented by visitors into the third century $\mathrm{BC}$, as shown by the plethora of objects of a corresponding range in date that were deposited in it, principally (imported) vessels for the transportation, preparation, and consumption of wine; alimentary vessels were also retrieved, as were burnt bones. ${ }^{37}$ Accordingly, the peripheral trench is interpreted as a sort of bothros and the moveable finds as votives or sacrifices given in veneration of the deceased.

The precise permutation of an offering trench dug around a prepared cremation zone and used for the deposition of artifacts and unburnt offerings of horses and human beings has no close parallels in the extra-Pontic Greek world. Although it is also an unicum in Greek mortuary archaeology, the Attic 'Opferrinne' may nevertheless be cited inasmuch as they too were pits constructed on a prepared ground, used for an ostentatious ceremonial destruction of offerings in conjunction with the cremation of the deceased (ALEXANDRIDOU, 2015; KISTLER, 1998; HOUBY-NIELSEN, 1996; HOUBY-NIELSEN, 1992). While the formal characteristics of the pits and ritual particularities of this ceremony differ vastly from those at Istros, both practices were developed by the elites in response to specific circumstances in their respective communities. The Opferrinne ceremony is essentially a Protoattic phenomenon, emerging at the end of the eighth century and diminishing in the first half of the sixth century BC. The whole ceremony, including the return to primary cremation, is thought by Sanne HoubyNielsen to be a "conscious archaism" performed in imitation of Homeric funerary ritual (HOUBY-NIELSEN, 1992, pp. 353-355).

Houby-Nielsen argues that these offering pits represent a shift in ritual communication away from the dead - who were cremated less visibly at the bottom of a shaft and buried with fewer grave goods - and toward the living community. The objects, principally banqueting implements, and small animals (birds) that were burned on the raised wooden platforms constructed over the Opferrinnen are not so much offerings to the dead as outward potsherds, a bronze stylus, and fragmentary parts of game boards. See LUNGU, 2015 and LUNGU, 2016. 
expressions of the aristocratic lifestyle that the deceased led (HOUBYNIELSEN, 1996, esp. pp. 47-51). The ritual is seen as an integral component of elite self-definition and the projection of identity in the formative decades of the Athenian polis. The peripheral pits at Istros are more short-lived than this: their use is confined to the latter half of the sixth century BC. Yet, they can also be considered a distinct iteration of atavistic epicizing behavior on the part of the colonial elite and as a means of asserting, in spectacular fashion, the distinction and distinctiveness of their dead (and, by extension, themselves). We will return to this point later.

It would be helpful to know if any elements of Istrian burial customs were translated from the mother city. Information about contemporary burial practices in Miletos is, however, on short supply. The documented tombs of Archaic date are inhumations dating to the second half of the sixth century. The most impressive of these is the so-called 'Lion tomb' at Kazartepe, which was a well-furnished monumental grave complex consisting of a large chamber and subterranean corridor cut into the hillside, accessed by a long dromos carved into the bedrock (FORBECK; HERES, 1997). In addition, a small number of Archaic-era monolithic sarcophagi have been uncovered in varying states of preservation during two different salvage operations in the same area of the modern village of Yeni Balat (which corresponds to the area of the ancient necropolis) (MÜLLER-WIENER; GÖKSEL; VON GRAEVE, 1988). These discoveries, which provide but a tantalizing glimpse into Archaic burial customs in Miletos, are unparalleled in the Istrian necropoleis. Yet, as Gillian Shepherd's comparative diachronic survey of Late Geometric to Late Archaic burial customs observed in the cemeteries of three neighboring Greek poleis in Sicily (Syracuse, Megara Hyblaia, and Gela) and their respective metropoleis has convincingly shown, colonies developed deliberately distinct burial practices, which did not simply duplicate those of the mother city (SHEPHERD, 1995). ${ }^{38}$ The relationship between Miletos and Istros may have possessed a similar dynamic, focused more on the expression of a distinct political identity than on the deferential adoption of the cultural forms and usages of its mother-city.

38 The conclusions in SHEPHERD, 2005, p. 132, are also instructive with respect to the presence of indigenous people or elements in West Greek necropoleis: "No site has produced graves which supply an ideal complete package of indigenous burial... This does not mean that cohabitation did not occur, but rather than any local traditions were largely subsumed to a prevailing Greek culture... What is more conspicuous is an overall subscription to a coherent burial system incorporating methods which cannot be connected readily with any one source and specifically not the historical mother-city." 
Of especial relevance to the interpretation of the Istrian tumuli is Shepherd's comparison of the customs of the neighboring Sicilian colonies. For instance, she finds that mid-seventh-century Megara Hyblaia saw the 'revival' of the monolithic stone sarcophagus, which one might see as a return to the customs of the mother city; yet, the late appearance of this development makes this reading less plausible. Instead, Shepherd argues that the use of such sarcophagi could have been inspired by nearby Syracuse, where such objects had already been commonly utilized but were becoming more restricted to the elites. That the monolithic sarcophagi were used for the burials of the general population at Megara Hyblaia can be understood as an act of "competitive emulation"; that is, "what was a statement of wealth and rank at [Syracuse] became at Megara Hyblaea merely the standard form of interment for the masses" (SHEPHERD, 1995, pp. 58-59).

Focusing in particular on the apparent chronological precedence not only of the 'heroon' of Orgame but also of the settlement itself vis-à-vis Istros, as well as their shared Milesian origin, Vasilica Lungu has conjectured instead that the Istrians revered the heroized Orgamean founder as a pioneer for their own community. In fact, following Alexandrescu, she posits that the Istrians may have ultimately settled, as it were, on the site of Istros after first occupying the naturally fortified position of Orgame. Accordingly, Lungu analogizes the potential significance of the Orgame 'heroon' for the Istrians to the etiological and ritual importance that the contemporary Archaic tumulus and later heroon 'of Aeneas' at Lavinium (which according to legend the Trojan hero founded) had for the Romans (LUNGU, 2008, pp. 160-162).$^{39}$ If a common oikistic lineage was claimed by Orgameans and Istrians, then the adoption of ostentatious tumular burials in the Northern Necropolis of Istros might be understood as complementary rather than competitive in nature - at least on the inter-communal level. Within Istros itself, the Archaic tumuli could have functioned in a variety of competitions between different classes of people in the city and/or within the aristocracy itself. This competition may have generated interpersonal violence, even resulting in death - especially if we admit the possibility that the ritual killing of the three human victims from Tumulus XVII was meant to appease the deceased through retribution.

Whether or not the communities of Istros and Orgame were of shared Milesian origin, they were neighbors and therefore would have been

39 She quotes ALEXANDRESCU, 1999, p. 24: "Les Histriens aussi, qui avaient peut-être hésités entre la place forte d'Orgamé et les larges perspectives du site d'Istros, se sont décidés pour le dernier.” 
in close contact. In the domain of commerce, for example, the quarries of Orgame (at Babadag) were likely the source of the Turonian limestone used in the construction of Istros' main sanctuary buildings (BÎRZESCU; BALTRES, 2013), which were erected around the same time as the oldest tumuli in the Northern Necropolis (mid-sixth cent. BC). Such interactions could have exposed the Istrians to the tombs of Orgame and served as an impetus for the Istrians to develop their own forms of the monuments. However, as will be discussed shortly, Istros' particular use of the tumulus would have had different implications. Rather than being a common form of burial at Istros, the tumuli also appear to have been restricted to an elite group. In this respect, the Istrians would not have been wholly deflating the (symbolic) value of the Orgame 'heroon' by adopting the practice of primary cremation under tumuli and particularly of unburnt peripheral offerings. Rather, the elite would have been elevating the significance of their own dead through the (modified) incorporation of a feature that at Orgame was unique to the 'heroon': the perimetric offering trench. The previous parenthetical qualification concerning modification refers to the form of the trench itself. While the trench of the Orgamean 'heroon' was discontinuous, the trench of Tumulus XVII is continuous. ${ }^{40}$

As was also proposed for Istros, each Sicilian colony had a variety of burial methods adopted by different social strata: at Syracuse the elite preferred monolithic stone sarcophagi while the larger populace utilized rockcut pits; at Megara Hyblaia the elite adopted hypogeic cellae while it was the general population that made use of the stone sarcophagi (SHEPHERD, 1995, pp. 58-59). This, I think, provides support for the notion that the Istrian tumuli (with primary cremation) was the custom instituted by the elite and was distinguished from a wider use of inhumation in flat pit graves. On this point, it is also interesting that these monumental tombs, as far as we can tell, first appear in Istros in the mid-sixth century - precisely when habitation of the city's residential zone is markedly more concentrated (cf. TIMOFAN, 2010). One wonders, following Zoe Petre, whether these tombs were adopted by the Istrian elite, or a subgroup thereof, as a strategy of differentiation from the

40 The trench of contemporary Tumulus XIX is also continuous. However, and interestingly, the earliest sixth-century tumulus at Istros (no. XX) has a discontinuous peripheral trench. Cf. ALEXANDRESCU, 1994, pp. 24 and 26, with figs. 9 and 11; ALEXANDRESCU, 1966, p. 145 fig. 14, 151 fig. 17. 
city's swelling population (PETRE, 2010, p. 33 and n. 14).$^{41}$ The suburban cemetery of Histria Bent ( $2.5 \mathrm{~km}$ from the city center), whose earliest graves predate the known tumuli of the Northern Necropolis by roughly fifty years, suggests the existence of distinct groups within the broader Istrian population that made use of different cemeteries and observed distinct burial customs. An exhaustive excavation of this cemetery uncovered 104 flat graves evidently belonging to Greeks and containing inhumations (pits for adults and enchytrismoi for children) and spanning from the beginning of the sixth to the first century BC (TELEAGĂ; ZIRRA, 2003). ${ }^{42}$ Over half of the 56 Archaic-era graves yielded grave goods; in some instances, the quantity and quality of these objects rival those of the tumuli. That being said, these graves could not compete with the ostentatious expenditure of energy, material, and indeed blood required for the construction of the cremation platforms, funerary pyres, and earthen tumuli, as well as the offering of quadrupeds and human beings.

While indigenous people also cremated their dead, they rarely built their tumuli directly over the site of the incinerated remains of the pyre (LUNGU, 2010, p. 538) ${ }^{43}$ Rather, the incinerated remains were gathered and then deposited secondarily in a pit, urn, stone cist, or on a platform of limestone slabs. Other distinctions may be noted between Greek and non-Greek cremation burials: Lungu notes, for instance, that the degree of burning achieved by Greek cremations was more intense, with the bones reaching full calcination (LUNGU, 2010, p. 539). ${ }^{44}$ This suggests two different incineration techniques. Furthermore, when it comes to animal offerings, it appears that the Greeks cast animal offerings directly into the flames of the pyre, perhaps whole, whereas indigenous people placed them

41 As far as the available archaeological evidence suggests, the transition into the Classical era sees the end of human and/or horse sacrifices in the context of the funerary rites at Istros; what is more, the final decades of the fifth century seem to coincide with a cessation of new tumulus construction in the necropolis. To explain this break in use, Petre proposes that sumptuary laws were implemented after the city's transition from oligarchy to democracy (cf. Arist. Pol. 1305b 1-13) in order to curtail ostentatious displays of elite wealth and power. Additionally, PETRE, 2010, p. 40, hypothesizes the existence of a different burial area for non-elites. 42 At a greater distance from the city center of Istros $(16 \mathrm{~km})$, at Corbu de Jos, rescue excavations brought to light evidence for another Greek cemetery in the form of seven flat inhumation graves, the earliest of which date from the late sixth to the beginning of the fifth century BC. For the latter cemetery see BUCOVALĂ, 1971. Interestingly, the Northern Necropolis also yielded a few examples of flat pit graves, for which see ALEXANDRESCU, 1966, pp. 230-231, with 203 fig. 44.

43 SIMION, 1998, pp.168-169, asserts that primary cremations were not a Thracian burial custom.

44 She compares the bones from cremations at Orgame (Greek) with those of Aegyssus, Celic Dere, Enisala, and Murighiol (indigenous). 
in vessels and deposited them within the tomb itself (ibid., p. 546). Finally, although Greek ceramics are present in Greek and non-Greek graves alike and are not, therefore, on their own reliable indicators of the ethnic identity of the deceased, the Istrian tumuli lack items typical of Thracian and Scythian tombs: Conspicuously absent among the grave goods are military equipment (e.g. Dacian swords, arrowheads) and jewelry (ibid., pp. 543-546; SÎRBU; ȘTEFAN; DUȚESCU, 2008, pp. 202-203; DAMYANOV, 2012, pp. 42-43). The goods offered to the deceased in the Archaic tumuli at Istros consisted overwhelmingly of ceramics, predominantly imported wares from Athens, East Greece, and Corinth. A few interesting metal objects were found, but nothing that epitomizes a Thracian or Scythian burial: an iron knife (with polishing stone) and the handle of a bronze mirror of the Scythian 'animal style' in Tomb XIX (ALEXANDRESCU, 1966, pp. 154 with pl. 85), and an iron knife in Tomb XII (ibid., p. 159).

Although the identity of the deceased ultimately cannot be determined with certainty, the Istrian tumuli should be incorporated into any consideration of Greek human sacrifice for the following reasons: a) none of the artifactual assemblages are typical of indigenous burials; b) the cremation burials are primary, not secondary; c) relatedly, indigenous cremations do not achieve complete calcination of the skeletal remains, indicating that the pyres do not burn as intensely or as long and thus that a different method was probably employed; d) while earthen tumuli were by no means an exclusively Greek form of sepulchral monument, in the region of Dobrudja the peripheral offering trench (discontinuous or continuous) is an element that is peculiar to the 'heroon' of Orgame and the Archaic tumuli at Istros; e) finally, given the evidence of the ritual slaughter of a human being from Pyre A at Eleutherna, the presence of human sacrificial victims in Tumulus XVII can no longer be considered a reliable indicator of non-Greek identity. Indeed, no contemporary indigenous burial in the region has yet yielded the entombed remains of human victims - or, for that matter, equine ones. ${ }^{45}$ One must venture further afield - to burial sites like those in the area of Sofronievo (NW Bulgaria; NIKOLOV, 1965, pp. 166170 ) and Belogradets (NE Bulgaria; Tumulus 4, grave 2; TONČEVA, 1980, p. 11) - to encounter the few documented, roughly contemporary $\left(i . e .7^{\text {th }}-6^{\text {th }}\right.$ cent. BC) Thracian tumuli containing the skeletal remains of horses. But

45 The tumuli may be called Greek, or at least Istrian, in the sense that SHEPHERD, 2005 proposed for West Greek colonies: a form of burial that is distinctive of the polis in which it was practiced. 
the abovementioned tombs differ substantially from their counterparts in the Northern Necropolis of Istros: Among the differences, the equine remains seem to have been positioned nearby the body of the deceased, toward the center of the tumulus; the equine and human remains are inhumed or show signs of partial cremation; the remains are positioned inside built compartments and/or encased beneath a layer of stones; and articles of horse tack and weaponry are among the burial goods. ${ }^{46}$

\section{Conclusion}

Having analyzed in detail the evidence from the Archaic-era tumulus XVII of the Northern Necropolis of Istros, I concur with Alexandrescu's judgment that the unburnt human skeletal remains correspond to victims of funerary sacrifice performed in connection with the cremation and entombment process. Although the tomb and its study did not produce a serviceable murder weapon or osteological evidence of peri-mortem trauma, the unusual positions of the bodies (unnaturally contorted and/or 'bound', and sometimes positioned face down) and the lack of accompanying grave goods nevertheless strongly suggest that the individuals were regarded not only as inferiors, but also that their deaths were violent, involuntary, perhaps even vindictive $\mathrm{e}^{47}$. The stratigraphy of the osteological remains shows that the killings took place before the tumuli were sealed. The identity of the victims cannot be known, though it seems safe to assume that they were regarded as inferiors based on their lack of proper burial. Beyond their status as victims,

46 While the horse was an important element of Thracian elite society, equestrian burials are rare in indigenous mortuary contexts prior to the Late Iron Age; cf. KOUZMANOV, 2005, with earlier bibliography. Thracians adopt the burial of horses along with human beings much later than the Greeks, as observed by GEORGIEVA, 2016, p. 272. For a recent collation and diachronic interpretation of the archaeological evidence for equine and weapon deposits in tombs in the broader area of Thrace, with further bibliography, see GEORGIEVA, 2016 (wherein Istros is briefly cited without any qualification regarding the ethnic or cultural identity of the deceased). It is important to recall here the paucity of martial equipment in the assemblages of the Late Archaic tumuli at Istros.

47 Face-down depositions of human remains are highly unusual in the mortuary record; they have been interpreted as deliberate, even contemptuous, efforts to dishonor the dead; cf. the comparative study of ARCINI, 2009. If there were such an emotional dynamic, this would point in the direction of sacrifices with a retributive dimension. 
we know nothing in particular about the individuals from Tumulus XVII ${ }^{48}$. Based on the analogy of the funeral of Patroklos, it is possible that these killings had a retributive dimension, although in the absence of evidence for the identity of the cremated deceased and the cause of his/her death, one cannot know for sure.

As Lungu has argued for the 'heroon' at Orgame, the tumuli at Istros can be seen as a means by which Milesian colonists could mark and shape the landscape of their new home, thereby projecting in a visually prominent way to neighboring peoples their wealth and might.

In the case of the 'heroon,' the massive funerary mound was heaped upon the promontory of Cape Dolojman, which would also have additionally made it a visible landmark for passing ships; here too an epic resonance could be detected. In Homeric epic, it is said that Achilles' tumulus was erected upon a promontory overlooking the Hellespont, to be seen by passing sailors (Hom. Il. 23.245-248, 7.84-90; Od. 24.80-84). Moreover, by the seventh century, Greeks were associating the tombs of Trojan War heroes (among them Achilles and Patroklos) with various earthen mounds (some actually corresponding to prehistoric settlements) along the northwest coast of the Troad. ${ }^{49}$ It is therefore tempting, albeit speculative, to question whether the early adoption of tumular burials at Orgame and Istros could have been additionally inspired by the experience of (Milesian) settlers sailing through the Hellespont en route to the Black Sea and seeing - perhaps with a stop at one of Miletos' colonies along the strait - the tumular monuments reputed to be those of celebrated epic heroes. This dynamic is all the more intriguing when one considers the Archaic-era localization of Achilles' afterlife abode in the once remote and unfamiliar Black Sea, as well as the development of a cult of Achilles along its northern shores - especially at the Milesian colony of Olbia (cf. BURGESS, 2009, esp. pp. 129-131; HUPE, 2006; HEDREEN, 1991). There was evidently an interest among the communities of the Milesian diaspora in engaging with the mortuary and commemorative dimensions of the heroic age in varying ways, each motivated or shaped by the particular social and political dynamics of the community.

48 The sacrificial victims discovered in the contemporary Tumulus XIX (550-525 BC) were both mature adults (in their thirties and early fifties, respectively), probably both men. As such they could have been servants or enemies of the cremated dead. Cf. NICOLĂESCU-PLOPȘOR, 1966, p. 371.

49 For tumular monuments and their role in, and influence upon, competition among communities and elites in the Troad cf. ROSE; KÖRPE, 2016. 
Jane Hjarl Petersen builds on Lungu's argument that the adoption of the tumulus form may have been a strategic choice, since this general form of burial monument was also used by indigenous people: Namely, the tumuli were monuments of power whose implications would not be lost on the natives (HJARL PETERSEN, 2010, pp. 119 [Orgame] and 260 [Orgame and Istros]). The performance of human and equine sacrifices at Istros, formerly regarded as the exclusive province of non-Greeks, might also have functioned in this way. By offering such victims, the Istrian elites (whether of Greek or mixed ethnicity) could have further communicated the importance of their dead relatives in a way that would have been readily understood by indigenous spectators. The fact that the tumuli were not heavily or sumptuously outfitted with goods prompts Petersen to propose that the Istrians preferred instead to show off their status outwardly with large mounds "and, possibly, funeral processions with horses and slaves or other humans for sacrifice" (ibid., p. 302).

To this, one may add the generally held belief that cremation and tumular burials were probably reserved for a specific, elite section of the Istrian population, since this necropolis and the burial customs observed therein were distinct from those seen in the cemeteries of the Istrian hinterland. ${ }^{50}$ While the funerary procedures and the tumuli in which they resulted may have been inspired, at least in a general sense, by elements of Greek epic (as known in poetic and/or 'real,' monumental form), as well as by the physically proximate example of the 'heroon' at Orgame, the message of this form of sepulchral monument (with the cremation ceremony that

50 DAMYANOV, 2005, p. 91, speculates that those buried in the tumuli were descendants of the first colonists. The tumular form of burial may have emerged suddenly, up to a century after the initial arrival of the Milesian settlers in the region, and in the context of accelerated population growth (AVRAM, 2006, pp. 63-64, proposes the arrival of a new wave of colonists around the mid- $6^{\text {th }}$ cent.; considering the context and proportions of indigenous pottery in Istros and its chora, DAMYANOV, 2018, p. 251, suggests that Thracians were gradually attracted to the Greek settlement's "zone of stability" and were part of the sixth-century "demographic surge"). Against this backdrop, the monuments do seem to be playing a highly visible role in the articulation and assertion of a distinct identity group within the Istrian populace. If these tumular burials were in some way associated with descendants of the first colonists, this descent need not have been based on actual, biological relations with the claimed ancestor(s). This is especially the case if the lineage was being traced back to the individual entombed within, and venerated at, the 'heroon' of Orgame; recall, for instance, that this is the only Orgamean tumulus with the peripheral trench, yet this feature is generalized, in continuous and discontinuous forms, among the sixth-century tumuli in Istros' Northern Necropolis. On the multiple kinds of ancestors and their various uses in ancient Greece, see ANTONACCIO, 2016. 
preceded it) was nevertheless 'multilingual' or polyvalent. ${ }^{51}$ Even as these monuments glorified and elevated the status of the deceased and his or her descendants in the eyes of the Pontic Greek communities, which doubtless included people of mixed parentage or ancestry, the significance of their fundamental elements would also have spoken to indigenous witnesses.

To mention indigenous and ethnically mixed people is to remind us of the problem of ethnicity and its discernibility in the archaeological record. The identity of the elite people who were cremated and buried within the tumuli of Istros may never be known with absolute certainty, although multiple factors suggest that they had some connection with the colonial Greek element of the community, through their own lineage or affinity with the particular group of Istrian elites who made use of these distinct mortuary rites. Whatever the reality, this case study of the Late Archaic tumulus XVII at Istros and its history in archaeological scholarship should remind us that human sacrifice cannot be taken as totally foreign to Greek culture or as a feature confined to some distant or even entirely mythical past. In fact, in the context of sixth-century Istros, this rite appears to have been conceived and introduced by an ethnically Greek or hybrid subset of the city's elite as a means of articulating a distinct group identity and claiming, through creative emulation of 'epic' behaviors, a pre-eminent position for themselves within the broader community.

\section{References}

ALEXANDRESCU, Petre. Sectorul 'Necropolei Tumulară'. Materiale și cercetări arheologice. Bucharest: Editura Academiei Republicii Populare Romîne, v. 6, 1959, pp. 289-299.

. Sectorul 'Necropolei Tumulare'. Materiale și cercetări arheologice. Bucharest: Editura Academiei Republicii Populare Romîne, v. 7, 1961, pp. 255-264.

. Les tertres funéraires d'Histria: Recherches archéologiques dans la nécropole tumulaire. Klio. Berlin: De Gruyter, v. 41, 1963, pp. 247-266. 
. Les rapports entre indigènes et Grecs à la lumière des fouilles de la nécropole d'Histria. In Le rayonnement des civilisations grecque et romaine sur les cultures périphériques. Paris: De Boccard, 1965a, pp. 336-339.

. Types de tombes dans la nécropole tumulaire d'Histria. Dacia. Bucharest: Cultura Națională, n.s. v. 9, 1965b, pp. 163-184.

. Necropola tumulară: Săpături 1955-1961. In CONDURACHI, Emil (org.). Histria II. Bucharest: Editura Academiei Republicii Socialiste România, 1966, pp. 133-294 [French summary pp. 409-422].

. Deux types de sépultures à incinération sur l'emplacement de la tombe. Dacia. Bucharest: Cultura Naţională, n.s. v. 15, 1971, pp. 319-324.

. Notes de topographie histrienne. Dacia. Bucharest: Cultura Națională, n.s. v. 22, 1978a, pp. 331-342.

. Histria IV: La céramique d'époque archaïque et classique $\left(V I I^{\mathrm{e}}-I V^{\mathrm{e}}\right.$ s.). Bucharest: Editura Academiei Republicii Socialiste România, 1978b.

. Un rituel funéraire homérique à Histros. In DE LA GENIÈRE, $\overline{\text { Juliette }}$ (org.). Nécropoles et sociétés antiques (Grèce, Italie, Languedoc): Acts du Colloque International du Centre de Recherches Archéologiques de l'Université de Lille III, Lille, 2-3 Décembre 1991. Cahiers du Centre Jean Bérard n. 18. Naples: Publications du Centre Jean Bérard, 1994, pp. 15-32.

. L'aigle et le dauphin: Études d'archéologie pontique, Paris: De Boccard, 1999.

ALEXANDRESCU, Petre; EFTIMIE, Victoria. Tombes thraces d'époque archaïque dans la nécropole tumulaire d'Histria. Dacia. Bucharest: Cultura Națională, v. 3, 1959, pp. 143-164.

ALEXANDRESCU, Petre; VÎLCEANU, Dumitru. Sectorul 'Necropolei Tumulare'. Materiale și cercetări arheologice. Bucharest: Editura Academiei Republicii Populare Romîne, v. 8, 1962, pp. 415-423.

ALEXANDRIDOU, Alexandra. Shedding Light on Mortuary Practices in Early Archaic Attica: The Case of the Offering Trenches. In HAGGIS, Donald C.; ANTONACCIO, Carla M. (org.). Classical Archaeology in Context: Theory and Practice in Excavation in the Greek World. Berlin: De Gruyter, 2015, pp. 121-147.

ANDREADAKI-VLAZAKI, Maria. Sacrifices in LM IIIB: Early Kydonia Palatial Centre. Pasiphae. Pisa: Fabrizzio Serra, v. 9, 2015, pp. 27-42. 
ANTONACCIO, Carla. Achieving Ancestorhood in Ancient Greece. In HILL, Erica; HAGEMAN, Jon B. (org.). The Archaeology of Ancestors: Death, Memory, and Veneration. Gainesville: University Press of Florida, 2016, pp. 102-123.

ARCINI, Caroline. Buried Face Down: Prone Burials. Current Archaeology. London: Current Publishing, v. 231, 2009, pp. 30-35.

AVRAM, Alexandru. Histria. In GRAMMENOS, Demetrios V.; PETROPOULOS, Elias K. (org.). Ancient Greek Colonies in the Black Sea. Thessaloniki: Archaeological Institute of Northern Greece, 2003, v. 1, pp. 280-340.

. The Territories of Istros and Kallatis. In GULDAGER BILDE, Pia;

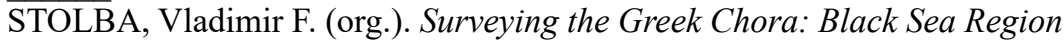
in a Comparative Perspective. Black Sea Studies n. 4. Aarhus: Aarhus University Press, 2006, pp. 59-80.

BÎRZESCU, Iulian; BALTRES, Albert. Noi date cu privire la originea și folosirea pietrei în 'Zona sacră' de la Histria în perioada arhaică. Studii și cercetări de istorie veche și arheologie. Bucharest: Editura Academiei Republicii Socialiste România, v. 64, 2013, pp. 3-19.

BLACKWELL, Nicholas G. Mortuary Visibility at Salamis (Cyprus): Relationships between and within the Royal Necropolis and the Cellarka Cemetery. Journal of Mediterranean Archaeology. Sheffield: Sheffield Academic Press, v. 23, 2010, pp. 143-167.

BONNECHERE, Pierre. Les indices archéologiques du sacrifice humain grec en question: Compléments à une publication récente" Kernos. Liège: Centre d'étude de la religion grecque antique, v. 6, 1993, pp. 23-55.

. Le sacrifice humain grec entre norme et anormalité. In BRULÉ, Pierre (org.). La norme en matière religieuse en Grèce ancienne: Actes du XIIe Colloque International du CIERGA (Rennes, septembre 2007). Kernos Supplements n. 21. Liège: Centre d'étude de la religion grecque antique, 2009, pp. 189-212.

BRAUND, David. Greek Religion and Cults in the Black Sea Region: Goddesses in the Bosporan Kingdom from the Archaic Period to the Byzantine Era. Cambridge: Cambridge University Press, 2018.

BUCOVALĂ, M., Irimia, M. Cimitirul din sec. VI-V î.e.n. de la Corbu, jud. Constanța. Pontica. Constanța: Muzeul de Arheologie Constanța, v. 4, 1971, pp. 41-56. 
BURGESS, Jonathan S. The Death and Afterlife of Achilles. Baltimore: Johns Hopkins University Press, 2009.

COLDSTREAM, John Nicholas. Geometric Greece: 900-700 BC. $2^{\text {nd }}$ ed. London; Routledge, 2003.

DAMYANOV, Margarit. Necropoleis and Ionian colonisation in the Black Sea. Ancient West \& East. Leiden: Brill, v. 4, 2005, pp. 77-97.

. Normative and Nonnormative Burial Practices in the Necropoleis of the Greek Colonies in the Western Black Sea Area. Ancient West \& East. Leiden: Brill, v. 11, 2012, pp. 35-68.

. First Encounters and Further Developments: Greeks Meeting Thracians on the Western Pontic Coast. In GIMATZIDIS, Stefanos; Pieniążek, Magda; MANGALOĞLU-VOTRUBA, Sila (org.). Archaeology across Frontiers and Borderlands: Fragmentation and Connectivity in the North Aegean and the Central Balkans from the Bronze Age to the Iron Age. Oriental and European Archaeology n. 9. Vienna: Verlag der Österreichischeen Akademie der Wissenschaften, 2018, pp. 243-268.

DONNELLAN, Lieve. Ethnic Identity in the Western Black Sea Area: The Cases of Histria, Kallatis, and Apollonia Pontika ( $7^{\text {th }}-4 / 3^{\text {rd }}$ Centuries BC). Talanta. Amsterdam: Elsevier, v. 36-37, 2004-2005, pp. 187-268.

. Funerary Rites as a Means of Land Appropriation. In AMUNDSENMEYER, Lindsay; ENGEL, Nicole; PICKERING, Seen (org.). Identity Crisis: Archaeological Perspectives on Social Identity. Proceedings of the 42 ${ }^{\text {nd }}$ (2010) Annual Chacmool Archaeology Conference, University of Calgary, Calgary, Alberta. Calgary: Chacmool Archaeological Association, University of Calgary, 2011, pp. 62-73.

EKROTH, Gunnel. The Sacrificial Rituals of Greek Hero-cults in the Archaic to Early Hellenistic Period. Kernos Supplements n. 12. Liège: Centre d'étude de la religion grecque antique, 2002.

FORBECK, Elke; HERES, Huberta. Das Löwengrab von Milet. Winckelmannsprogramm der archäologischen Gesellschaft zu Berlin n. 136. Berlin: De Gruyter, 1997.

GEORGIEVA, Rumyana. Riders' Burials in Thrace. In HENRY, Olivier; KELP, Ute (org.). Tumulus as Sema: Space, Politics, Culture, and Religion in the First Millennium BC, Berlin: De Gruyter, 2016, pp. 269-280. 
HALL, Jonathan M. Hellenicity: Between Ethnicity and Culture. Chicago: University of Chicago, 2002.

HEDREEN, Guy. The Cult of Achilles in the Euxine. Hesperia. Cambridge: Harvard University Press, v. 60, n. 3, 1991, pp. 313-330.

HENRY, Olivier; KELP, Ute (org.). Tumulus as Sema: Space, Politics, Culture, and Religion in the First Millennium BC, Berlin: De Gruyter, 2016.

HOUBY-NIELSEN, Sanne. Interaction between Chieftains and Citizens? $7^{\text {th }}$ century B.C. Burial Customs in Athens. Acta Hyperborea. Copenhagen: Museum Tusculanum Press, v. 4, 1992, pp. 343-374.

. The Archaeology of Ideology in the Kerameikos: New Interpretations of the Opferrinnen. In HÄGG, Robin (org.). The Role of Religion in the Early Greek Polis: Proceedings from the Third International Seminar on Ancient Greek Cult, Organized by the Swedish Institute at Athens, 16-18 October 1992. Stockholm: Svenska Institutet i Athen, 1996, pp. 41-54.

HJARL PETERSEN, Jane. Cultural Interactions and Social Strategies on the Pontic Shores: Burial Customs in the Northern Black Sea Area c. 550270 BC. Aarhus: Aarhus University Press, 2010.

HUGHES, Dennis. Human Sacrifice in Ancient Greece. New York: Routledge, 1991.

HUPE, Joachim (org.). Der Achilleus-Kult im nördlichen Schwarzmeerraum vom Beginn der griechischen Kolonisation bis in die römische Kaiserzeit; Beiträge zur Akkulturationsforschung. Internationale Archäologie n. 94. Rahden: M. Leidorf, 2006.

IVANTCHIK, Askold I. The Funeral of Scythian Kings: The Historical Reality and the Description of Herodotus (4.71-4.72). In BONFANTE, Larissa (org.). The Barbarians of Ancient Europe: Realities and Interactions. Cambridge: Cambridge University Press, 2011, pp. 71-106.

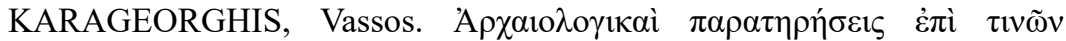
ó Philologon Kyprou “Stasinos", v. 1, 1963, pp. 31-39.

. Nouvelles découvertes dans la nécropole royale de Salamine de Chypre. In Le rayonnement des civilisations grecque et romaine sur les cultures périphériques: Huitième Congrès International d'Archéologie Classique (Paris, 1963). Paris: De Boccard, 1965, pp. 305-312. 
Salamis III: Excavations in the Salamis Necropolis I. Nicosia: Published for the Republic of Cyprus by the Department of Antiquities, Cyprus, 1967.

. Heroic Burials in Cyprus and Other Mediterranean Regions. In STAMPOLIDIS, Nicholas Chr.; KARAGEORGHIS, Vassos (org.). ПИOE $\Sigma . .$. Sea routes: Interconnections in the Mediterranean $16^{\text {th }}-6^{\text {th }} c$. BC. Proceedings of the International Symposium held at Rethymnon, Crete September $29^{\text {th }}$-October $2^{\text {nd }} 2002$. Athens: University of Crete and the A.G. Leventis Foundation, 2003, pp. 339-351.

KISTLER, Erich. Die 'Opferrinne-Zeremonie': Bankettideologie am Grab, Orientalisierung und Formierung einer Adelsgesellschaft in Athen. Stuttgart: Steiner, 1998.

KOUZMANOV, Momchil. The Horse in Thracian Burial Rites. In BOUZEK, Jan; DOMARADZKA, Lidia (org.). The Culture of the Thracians and Their Neighbours: Proceedings of the International Symposium in Memory of Prof. Mieczyslaw Domaradzki, with a Round Table "Archaeological Map of Bulgaria.” Oxford: Archaeopress, 2005, pp. 143-146.

LUNGU, Vasilica. La tombe d'un "HP $\Omega \Sigma$ et l'organisation de la nécropole d'une cité milésienne du Pont Euxin: Le tumulus T-A95 d'Orgamé. Talanta. Amsterdam: Elsevier, v. 32-33, 2000-2001, pp. 171-188.

. Hero Cult and Greek Colonization in the Black Sea Area. Revue des études sud-est européennes. Bucharest: Editura Republicii Socialiste România, v. 40, 2002, pp. 3-17.

. Nécropoles grecques du Pont gauche: Istros, Orgamé, Tomis, Callatis. In GRAMMENOS, Demetrios V.; PETROPOULOS, Elias K. (org.). Ancient Greek Colonies in the Black Sea 2. Oxford: Archaeopress, 2007, vol. 1, pp. 337-382.

- Les funérailles de Patrocle et les plus anciennes nécropoles ioniennes de la mer Noire. In ÖZBEK, Onur (org.). Funeral Rites, Rituals and Ceremonies from Prehistory to Antiquity: Proceedings of the International Workshop "Troas and Its Neighbors," Çanakkale and Ören 2-6 October 2006. Istanbul: Institut Français d'Études Anatoliennes, 2008, pp. 154-170.

. Pratiques funéraires chez les Grecs et les indigènes en Dobroudja septentrionale. In TRÉZINY, Henri (org.). Grecs et indigènes de la Catalogne à la Mer Noire: Actes des rencontres du programme européen Ramses 2 (2006-2008). Paris: Errance, 2010, pp. 537-554. 


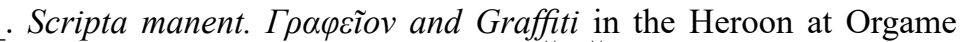
(Argamum, Jurilovca, Tulcea County). In VĂTĂȘESCU, Cătălina (org.). Mélanges historiques publiés à l'occasion du XIe Congrès de l'Association Internationale d'Études du Sud-Est Européen, Sofia, 31 Août - 4 Septembre 2015, Bucharest: Editura Academiei Române, 2015, pp. 169-180.

. Not Any Man Is Fortunate in the Glory of Games. Ancient West \& East. Leiden: Brill, v. 15, 2016, pp. 147-160.

. Architectural Finds and Founder Cult Evidence in the Heroon at Orgame. Caiete ARA. Bucharest: Editura ARA, v. 8, 2017, pp. 17-30.

MCGEORGE, Photini J.P. The Earliest Archaeological Evidence for a Mycenaean Greek Ritual Form of Human Sacrifice. Pasiphae. Pisa: Fabrizzio Serra, v. 9, 2015, pp. 43-52.

MÜLLER-WIENER, Wolfgang; GÖKSEL, Dogu; VON GRAEVE, Volkmar. Notgrabung in der archaischen Nekropole von Milet. Deutsches Archäologisches Institut, Abteilung Istanbul. Istanbul: Das Institut, v. 38, 1988, pp. 253-278.

MURRAY, Augustus Taber (trans.). Homer, The Iliad. Loeb Classical Library. Cambridge: Harvard University Press, 1925 [1976], v. 2.

MYLONA, Dimitra. Sacrifices in Minoan LM IIIB: Early Kydonia Palatial Centre. The Animal Remains. Pasiphae. Pisa: Fabrizzio Serra, v. 9, 2015, pp. 53-58.

MYLONOPOULOS, Ioannis. Gory Details? The Iconography of Human Sacrifice in Greek Art. In BONNECHERE, Pierre; GAGNÉ, Renaud (org.). Sacrifices humains: Perspectives croisées et représentations. Collection Religions: Comparatisme - Histoire - Anthropologie n. 2. Liège: Presses universitaires de Liège, 2013, pp. 61-85.

NICOLĂESCU-PLOPŞOR, Dardu. Données anthropologiques préliminaires sur les squelettes humains des tombes thraces d'Histria. Dacia. Bucharest: Cultura Națională, n.s. v. 3, 1959, pp. 165-178.

. Studiu antropologic al osemintelor umane descoperite la Histria în necropola tumulară. In CONDURACHI, Emil (org.). Histria II. Bucharest: Editura Academiei Republicii Socialiste România, 1966, pp. 355-381.

NIKOLOV, Bogdan. Trakijski pametnici văv Vračansko. Izvestiia na Arkheologicheskiia Institut. Sofia: Arkheologicheskiia Institut, v. 28, 1965, pp. 163-202. 
OPPERMANN, Manfred. Die westpontischen Poleis und Ihr indigenes Umfeld in vorrömischer Zeit. Langenweißbach: Beier \& Beran, 2004.

PETRE, Zoe. Пí $\mu \pi \lambda \alpha$ $\alpha$ pı̀̀v: Le symposion à Istros. In ANGELESCU, Mircea Victor; ACHIM, Irina; BÂLTÂC, Adela; RUSU-BOLINDET, Viorica; BOTTEZ, Valentin (org.). Antiquitas Istro-Pontica: Mélanges d'archéologie et d'histoire ancienne offerts à Alexandru Suceveanu. ClujNapoca: Mega, 2010, pp. 11-13, 31-43.

POPHAM, Mervyn Reddaway; CALLIGAS, Petros G.; SACKETT, L. Hugh (org.). Lefkandi II: The Protogeometric Building at Toumba. Part 2: The Excavation, Architecture, and Finds. London: Thames and Hudson for the British School of Archaeology at Athens, 1993.

RABADJIEV, Kostadin. The Thracian Tomb as Ritual Space of the Beyond. In HENRY, Olivier; KELP, Ute (org.). Tumulus as Sema: Space, Politics, Culture, and Religion in the First Millennium BC, Berlin: De Gruyter, 2016, pp. 281-311.

ROSE, C. Brian; KÖRPE, Reyhan. The Tumuli of Troy and the Troad. In HENRY, Olivier; KELP, Ute (org.). Tumulus as Sema: Space, Politics, Culture, and Religion in the First Millennium BC, Berlin: De Gruyter, 2016, pp. 373-386.

SHEPHERD, Gillian. The Pride of Most Colonials: Burial and Religion in the Sicilian Colonies. In FISHER-HANSEN, Tobias (org.). Ancient Sicily. Acta Hyperborea n. 6. Copenhagen: Museum Tusculanum Press, 1995, pp. 51-82.

. Dead Men Tell No Tales: Ethnic Diversity in Sicilian Colonies and the Evidence of Cemeteries. Oxford Journal of Archaeology. Oxford: Blackwell, v. 24, 2005, pp. 115-136.

SIMION, Gavrilă. Nécropoles des bouches du Danube: Pratiques, rituels, funéraires et ethnicité (VIe s. av. J.-C. - IIe s. ap. J.-C.). In MARCHEGAY, Sophie; LE DINAHET, Marie-Thérèse; SALLES, Jean-François (org.). Nécropoles et pouvoir. Idéologies, pratiques et interprétations: Actes du colloque Théories de la nécropole antique, Lyon 21-25 janvier 1995. Lyon: Maison de l'Orient et de la Méditerranée Jean Pouilloux, 1998, pp. 167-190.

SÎRBU, Valeriu. Sacrifice humains et pratiques funéraires insolites dans l'areal thrace du Hallstatt et du La Tène. In SIMION, Gavrilă (org.). Premier Âge du fer aux bouches du Danube et dans les régions autour de la Mer Noire: Actes du Colloque International, Septembre 1993, Tulcea. Tulcea: Institutul de Cercetări Eco-Muzeale, 1993 [1997], pp. 193-211, 295-296. 
SÎRBU, Valeriu; ȘTEFAN, Dan; DUȚESCU, Magdalena. Telița - Celic Dere, Tulcea County: Landscape Studies. In SÎRBU, Valeriu; ȘTEFĂNESCU, Radu (org.). Funerary Practices in Central and Eastern Europe $\left(10^{\text {th }} \mathrm{c} . B C\right.$ $-3^{\text {rd }}$ c. AD): Proceedings of the $10^{\text {th }}$ International Colloquium of Funerary Archaeology Tulcea (Dobruja-Romania) $10^{\text {th }}-12^{\text {th }}$ of October 2008. Brăila: Editura Istros - Muzeul Brăilei, 2008, pp. 201-214.

STAMPOLIDIS, Nicholas Chr. Antipoina: "Reprisals". Contribution to the Study of Customs of the Geometric-Archaic Period. Rethymno: University of Crete, 1996.

TELEAGĂ, Emilian; ZIRRA, Vlad. Die Nekropole des 6.-1. Jhs. von Istria Bent bei Histria. Archäologische Untersuchungen zur Bevölkerung in der westlichen Schwarzmeerregion. Rahden: Verlag Marie Leidorf, 2003.

TIMOFAN, Anca. Archaic Domestic Architecture and Construction Techniques on the Western Plateau of Histria: A Synthesis of Building Activity in the Black Sea Area $\left(7^{\text {th }}-6^{\text {th }}\right.$ centuries BC). In ANGELESCU, Mircea Victor; ACHIM, Irina; BÂLTÂC, Adela; RUSU-BOLINDET, Viorica; BOTTEZ, Valentin (org.). Antiquitas Istro-Pontica: Mélanges d'archéologie et d'histoire ancienne offerts à Alexandru Suceveanu. ClujNapoca: Mega, 2010, pp. 355-372.

TONČEVA, Goranka. Nécropole tumulaire près du village Belogradec du VIIe s. av. n. ère. Dacia. Bucharest: Cultura Naţională, v. 5, 1980, pp. 5-52.

USTINOVA, Yulia. The Supreme Gods of the Bosporan Kingdom: Celestial Aphrodite and the Most High God. Leiden: Brill, 1999.

WEST, Martin L (org. and trans.). Greek Epic Fragments: From the Seventh to the Fifth Centuries BC. Loeb Classical Library. Cambridge: Harvard University Press, 2003. 